\title{
Title: Global food security and food riots - an agent-based modelling approach
}

Authors: Natalini, Davide ${ }^{1, *}$; Bravo, Giangiacomo ${ }^{2,3}$; Jones, Aled Wynne ${ }^{1}$

1 Global Sustainability Institute, Anglia Ruskin University, East Road, Cambridge CB1-1PT, UK;

2 Department of Social Studies, Linnaeus University, Universitetsplatsen 1, 35195 Växjö, Sweden;

3 Linnaeus University Center for Data Intensive Sciences \& Applications (DISA@LNU), Växjö,

Sweden;

* Author to whom correspondence should be addressed; E-Mail: davide.natalini@anglia.ac.uk; Tel.: $+44-8451-965115$

\begin{abstract}
:
Due to negative consequences of climate change for agriculture and food production shocks affecting different areas of the world, the past two decades saw the conditions of global food security increasingly worsen. This has resulted in negative consequences for the world economy, partly causing international food price spikes and social upheavals. In this paper we present statistical findings along with a preliminary version of an original agent-based model called the Dawe Global Security Model that simulates the global food market and the political fragility of countries. The model simulates the effects of food insecurity on international food prices and how these, coupled with national political fragility and international food trade can, in turn, increase the probability of food riots in countries. The agents in the model are the 213 countries of the world whose characteristics reflect empirical data and the international trade of food is also simulated based on real trade partnerships and data. The model has been informed, calibrated and validated using real data and the results of these procedures are presented in the paper. To further test the model we also present the model's forecasts for the near future in terms of food prices and incidence of food riots. The Dawe Global Security Model can be used to test scenarios on the evolution of shocks to global food production and analyse consequences for food riots. Further developments of the model can include national responses to food crises to investigate how countries can influence the spread of global food crises.
\end{abstract}

Keywords: food security, agent-based model, food riots, fragility, forecast, international trade.

Acknowledgements: the authors would like to thank Alexander Phillips, research assistant at the Global Sustainability Institute, who collaborated in a previous version of this paper. In addition, the authors would like to thank the reviewers, whose suggestions definitely improved the quality of this paper. The work related to this paper has been supported by the Dawe Charitable Trust.

\section{Introduction}

Food security, here defined as the global availability of food capable of meeting global food demand, has become one of the main priorities of the international political agenda following the 2008 global food crisis, which exposed the fragilities of the current structure of the international food system and which had severe consequences for poverty and conflict around the world. The 2008 global food crisis is indeed a clear example of how localised food production shocks can travel through networks and have important consequences for the global economy, which can generate reinforcing feedbacks that result in widespread political fragility and, in particular, food riots. This crisis was part of a globalised, multi-system crisis recently called 'Synchronous Failure' (Homer-Dixon, et al., 2015), and is a new type of crisis which involves failures within different parts of the Socio-Ecological System, which synchronise and can cause social unrest and fragility.

The interconnectedness of the global food system through international trade entails both positive and negative consequences for global food security. Positive in terms of providing food supplies to countries that cannot grow enough food to feed their own populations, and negative in terms of the possibility of shocks to propagate through the global food supply chain, causing disruptions in different countries. On this last point, Puma, et al. (2015) and the report by Bailey, et al. (2015) found that the high interconnectivity of the global food system makes it vulnerable to self-propagating disruptions in case of a climate-related extreme event and that interconnectivity on the trade network is growing, with countries increasingly relying on food imported from a few large producer-exporters. 
Studies on global food security usually focus on solutions to provide a future balance between consumption and supply of food (Rosegrant and Cline, 2003; Schmidhuber and Tubiello, 2007; Godfray, et al., 2010; Anderson, 2010; Calzadilla, et al., 2011), which is a reductionist perspective of food security. A comprehensive account of how shocks to global production of food propagate through the international food system to give life to political instability and food riots is missing. Puma, et al. (2015) are the first to attempt to evaluate the resilience of the global food system, although their research only implemented a global network analysis and did not explore the consequences of food insecurity in terms of national political fragility and food riots. Raleigh, et al. (2015) went further by assessing and modelling the feedbacks between conflict, food prices and climate change, but their research only focussed on African countries, and hence their findings cannot be generalised.

Future projections on climate change that are expected to worsen global food insecurity (Rosegrant and Cline, 2003; Schmidhuber and Tubiello, 2007; Maxwell, et al., 2010; Godfray, et al., 2010; Huang, et al., 2011; Berazneva and Lee, 2013; Wheeler and von Braun, 2013), alongside more common international food price spikes (Berazneva and Lee, 2013) and more frequent food riots (Smith, 2014) make these interactions worth exploring with a systemic approach to test the consequences of what-if scenarios and possible policy interventions. Puma, et al. (2015) call for further research in the dynamics of the system and possibly in systemic risk, as do other authors (Schweitzer, et al., 2009; Wheeler and von Braun, 2013; Raleigh, et al., 2015). In fact, quantitative research in the global food security field is scarce and the authors that have used a quantitative approach mainly implemented econometric techniques (e.g. Berazneva and Lee, 2013 or Raleigh, et al., 2015), which lack the possibility of introducing and evaluating the effects of feedbacks between food security, the international economy and the occurrence of food riots.

One effective methodology that can start to disentangle the several relationships that characterise the complexity of the global food system is computer simulation. Only specific sectors and dynamics of the food system have been modelled in the past. Research particularly focussed on technology diffusion (e.g. Purvis, et al., 1995), land-use change (e.g. Loibl and Toetzer, 2003), impacts of climate change (e.g. Naylor, et al., 2007), policy analysis and testing (e.g. Waddell, 2000), consequences of changes in crop yield (e.g. Coble, et al., 2000) and the dynamics of the agricultural system more in general (e.g. Pasqualino, et al., 2015).

Several modelling approaches are available. We chose Agent-Based Modelling (ABM) as it allows reproduction of the details of the complex dynamics characterising socio-ecological systems better than existing alternatives (Gilbert and Terna, 2000; Gilbert, 2008; Thiele, et al., 2011; Railsback and Grimm, 2012; Filatova, et al., 2013). ABM has been used in the agricultural sector to model technology diffusion (e.g. Berger, 2001), micro-scale market dynamics (e.g. Arsenault, et al., 2012), scenario and policy testing (e.g. Bastardie, et al., 2010), land use change (e.g. Zhang, et al., 2013), decision-making (e.g. Ng, et al., 2011) and land price dynamics (e.g. Filatova, et al., 2009). A systemic view of how food production shocks can translate into an increased probability of the occurrence of food riots in the world is missing from current literature, which is the gap that is addressed by this paper.

The novelty of this research lies in the systemic approach adopted and in the development of a tool that can be of future use to test the consequences of food production shocks in terms of social unrest. In this paper we present the update of a quantitative analysis on some of the drivers of food riots previously published in Natalini, et al. (2015) and the structure of a novel ABM called the Dawe Global Security Model (DGSM), its calibration with the recent global food crisis, validation and future forecasts. The main aim of the DGSM is to model the dynamics that lead from international food security to the occurrence of food riots. This model represents a first attempt to simulate the complex dynamics that lead from global production shocks to the occurrence of food riots. In particular, the purpose of the model is to simulate how scarcity of food, its international price and national political fragility influence the probability of food riots in countries, also accounting for international food trade. The ultimate aim of the DGSM is to analyse the possible impacts of climate-related food production shocks and how these reverberate through the system, particularly focussing on the occurrence of food riots in countries. Although the ABM is still at a preliminary stage of development, its validation has led to promising results and we present forecasts for the year 2017. To model the relationship between the international price of food, national political fragility and food riots we extensively drew on the results from Natalini, et al. (2015) updating their results by extending their research both in time and geographically, 
In the next section of this paper we present the current literature on the topics discussed in this paper. Section 3 will introduce the updated analysis on the relationship between food prices, fragility and food riots based on Natalini, et al. (2015). The fourth section will present the ABM and how the previous section analysis has been incorporated in the model. Section 5 will present the 2017 forecast and finally we will present our conclusions in Section 6.

\section{Food insecurity and food riots}

The global food system is a complex system of interrelated sectors such as physical (e.g. production of food), social (e.g. consumption of food), economic (e.g. price of food) and political (e.g. policies for food system). Changes in one sector can potentially have severe consequences for one or more of the others. A growing body of research has been dedicated to the study of these complex interactions and evidenced the existence of a vicious cycle between conflict, high international prices of food and food insecurity (Devereux and Maxwell, 2001; Auyero and Moran, 2007; Brinkman and Hendrix, 2011; Raleigh, et al., 2015).

The main drivers of food insecurity are long-term social trends such as an increasing global population, environmental and climatic changes and international conflict (Godfray, et al., 2010; Brinkman and Hendrix, 2011; Calzadilla, et al., 2011; Berazneva and Lee, 2013; Puma, et al., 2015), which are expected to increase in the future hence worsening the conditions of global food insecurity.

Previous literature explored the possible consequences of food (in)security, particularly highlighting a positive relationship between global scarcity of food and increases in international food prices (Godfray, et al., 2010; Raleigh, et al., 2015; Puma, et al., 2015), but also between global scarcity of food and increased probability of conflict (Brinkman and Hendrix, 2011; Raleigh, et al., 2015). Other authors also argued that food insecurity increases the chances of democratic breakdown in politically fragile countries (Brinkman and Hendrix, 2011).

At the same time, high international food prices can impact food security (Brinkman and Hendrix, 2011; Berazneva and Lee, 2013; Hendrix and Brinkman, 2013; Bellemare, 2014; Smith, 2014; Raleigh, et al., 2015) and the political stability of countries (Seddon and Walton, 1994; Arezki and Bruckner, 2011; Bates, 2011; Berazneva and Lee, 2013), also causing political changes at the national level (Brinkman and Hendrix, 2011).

The vicious cycle between food insecurity, international prices and unrest depicted above was clearly evident during the most recent wave of food riots. These events may have initially been motivated by issues around lack of access to food, which then transformed into a generalised dissent and discontent with the current establishment (O'Brien, 2012). Indeed, food riots are widely believed to negatively affect the political stability of countries (Crawley, et al., 2012) and that the political instability and unrest created can spread to neighbouring countries (Lagi, et al., 2011) and through networks (Puma, et al., 2015). Goldstone (2011), for instance, argued that these events can trigger larger grievances such as civil wars, as in the case for the French Revolution and the Arab Spring.

Food riots have been defined as "violent, collective unrest leading to a loss of control, bodily harm or damage to property, essentially motivated by a lack of food availability, accessibility or affordability, as reported by the international and local media, and which may include other underlying causes of discontent" (Cuesta, 2014). Although the 2008 global food crisis triggered increased research on the interconnections between scarcity of food, international food prices and food riots, violent uprisings related to the price of food or scarcity thereof had been occurring for the past four centuries (Brinkman and Hendrix, 2011; Berazneva and Lee, 2013; Smith, 2014; Demarest, 2014).

Since 2008 research has thus been focussing on the drivers of food riots, which notably are food insecurity (Lagi, et al., 2011; Crawley, et al., 2012) and high international food prices (Hendrix, et al., 2009; Lagi, et al., 2011; Gaub, 2012; Crawley, et al., 2012; Bellemare, 2014; Smith, 2014; Bleischwitz, et al., 2014; Natalini, et al., 2015). However, the literature about the most recent ( $21^{\text {st }}$ century) food riots found that food insecurity and high international food prices are neither a sufficient or necessary conditions for food-related unrest to happen. Indeed, some authors argued that international prices for food rarely translate perfectly into national prices for the same commodities (Brinkman and Hendrix, 2011; Smith, 2014; Raleigh, et al., 2015), although Smith (2014) still found a positive relationship between a sudden increase in domestic food prices and urban unrest. Several authors argue that 
countries are more likely to experience food riots where there are food production shocks (e.g. King, et al., 2015) or if a country is a net food importer (e.g. Lagi, et al., 2011). However, these arguments are challenged by part of the literature. For instance, Buhaug, et al. (2015) found no evidence of a link between reduced agricultural output and an increase in the incidence of food riots in Sub-Saharan Africa. Similarly, Natalini, et al. (2015) did not find a positive relationship between national food scarcity and the occurrence of food riots. This opinion is shared by other authors who believe that scarcity of food is not a direct cause of food riots, but rather a catalyst (e.g. Sneyd, et al., 2013). Finally, several authors found that food riots are more likely to occur in countries that are already politically fragile (Brinkman and Hendrix, 2011; Natalini, et al., 2015).

The research on the drivers of food riots is comprehensive, but findings are contradictory and the methodologies implemented were not always appropriate. For instance, Lagi, et al. (2011) identified a threshold on the price of food as captured by the Food and Agriculture Organisation (FAO) Food Price Index (FAO FPI) over which food riots are more likely to occur. This was set at 210 for the nominal version of the index. However, as highlighted by Natalini, et al. (2015) the database of food riots used by Lagi, et al. (2011) was inaccurate and the quantitative tests implemented inappropriate. In addition, the paper was never published in an academic peer-reviewed journal. Bellemare (2014) investigated both food price increases and food price volatility as possible causes of food riots. His results show no significant connection between food price volatility and the occurrence of food riots, whereas food price increases significantly affect this type of event, also providing causal evidence between the first two dynamics. However, an in-depth review of the article raised concerns on the author's database on food riots, in particular, this could not be reproduced as it was collected through newspaper search engines that require an academic subscription, and, in addition, these databases add and remove entire newspapers at their own discretion, making the reproduction of the author's database (and hence results) difficult. Finally, Natalini, et al. (2015) evaluated some the drivers of food riots occurred in the Middle East, North Africa and Asia regions between 2005 and 2011. The authors found that national scarcity of food does not significantly impact the occurrence of food riots, as opposed to international food prices, whose relationship with food riots was significant. In particular, the authors found a methodologically robust threshold for the FAO FPI over which food riots are more likely to occur. This was set at 148 for the deflated version of the index. However, the database of food riots used in that study presented geographical and time constraints. The first part of the research presented in the next section of this paper hence constitutes a geographic and time update of the paper of the paper of Natalini, et al. (2015).

\section{An update of the food, price and fragility nexus}

Since the aim of the DGSM was to recreate the dynamics that could lead to an increase in the probability of food riots for countries and possibly forecast them, we used the findings from Natalini, et al. (2015) to inform this part of the model. In particular, the research found that food riots are more likely to occur when the Food and Agriculture Organisations' Food Price Index (FAO FPI) (FAO, 2015) went beyond a threshold of 148 . However, this research only covered the period $2005-2011$ and was limited to countries in Africa, Middle-East and Asia. We thus updated their database of food riots to 2013 also including all the areas of the world and reran their econometric tests to find a more accurate threshold for the FAO FPI.

Using the definition of food riots presented in the previous section (the same as used by Natalini, et al. (2015)), we carried out a simple keyword search to find newspaper articles in English that met the definition of food riots. To add more entries to the database we also used the database on food riots developed by the Food Price Crisis Observatory from the World Bank (WB, 2015a), assuming that their records were correct. The manual search for online media articles was preferred to the use of larger, online media repositories because we wish our research to be publicly available, open-access and easy to replicate. Data gathered through online repositories is often protected by copyright and their use is restricted to academic institutions that hold a valid licence. It is also important to note at this stage the limitations of our data collection methodology. Our database is indeed deemed to be partially incomplete as our search was only carried out in English and on online newspapers. Therefore, local food riots that were not large enough to be reported, or that were only reported in local printed newspapers or that were reported in a language different from English, would not have been captured in our database. In addition, the use of a strict definition of food riots and a keyword search will miss cases of instability and riots where food price inflation plays a role, yet where it is not specifically mentioned in media reports. Despite these important limitations, our database still retains 
the largest number of violent food riots recorded amongst the databases reviewed for our analysis (e.g. Food Price Crisis Observatory).

Figure 1 presents the updated database of food riots in the form of a timeline. This data arranged in a table is also available in Appendix 1 with references and is graphically displayed alongside the deflated version of the FAO FPI in Figure 2.

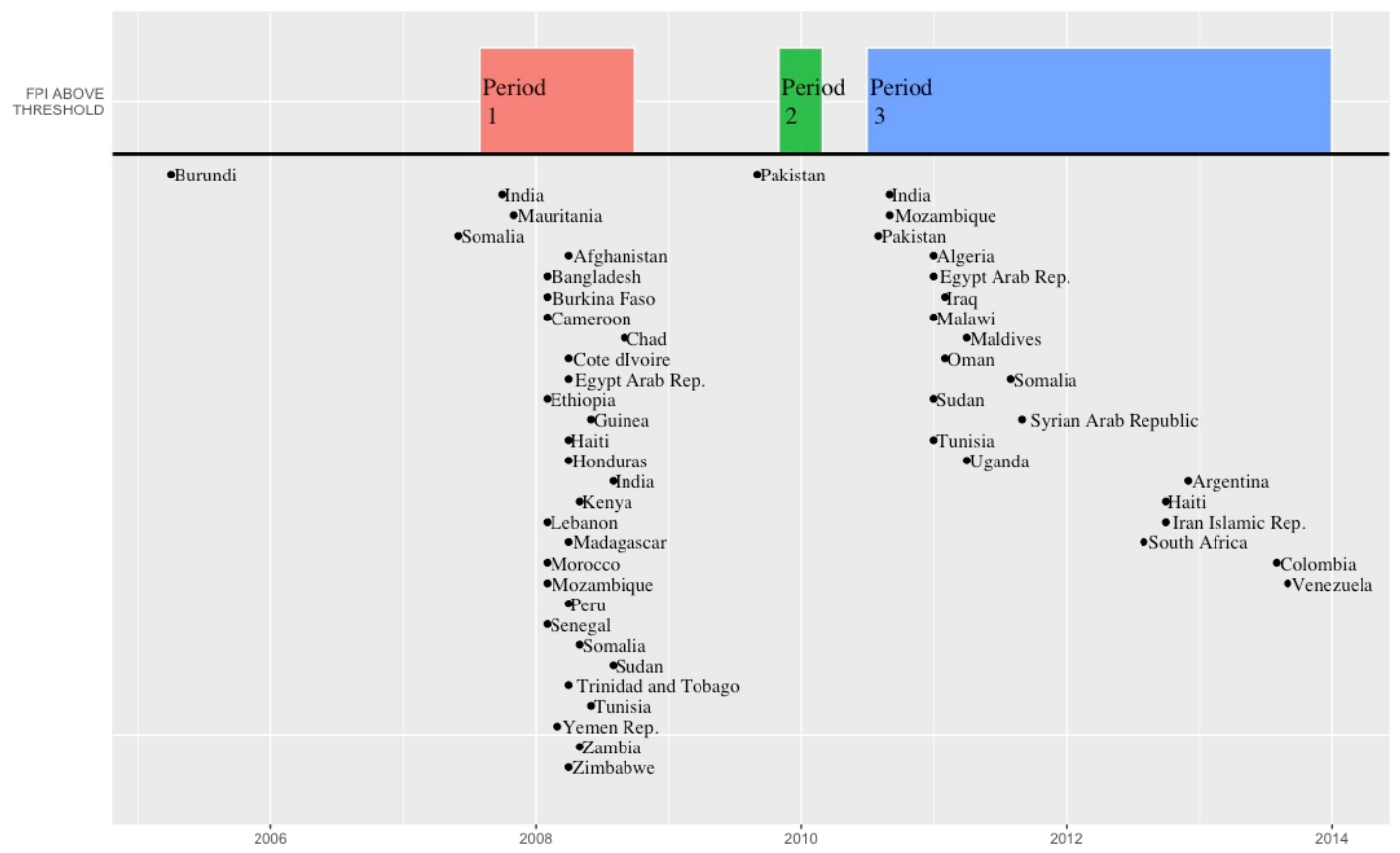

Fig. 1 Timeline with database for food riots. The top part of the figure highlights the periods when the FAO FPI was above the threshold, whereas the bottom part of the figure shows countries that experienced food riots between 2005 and 2013.

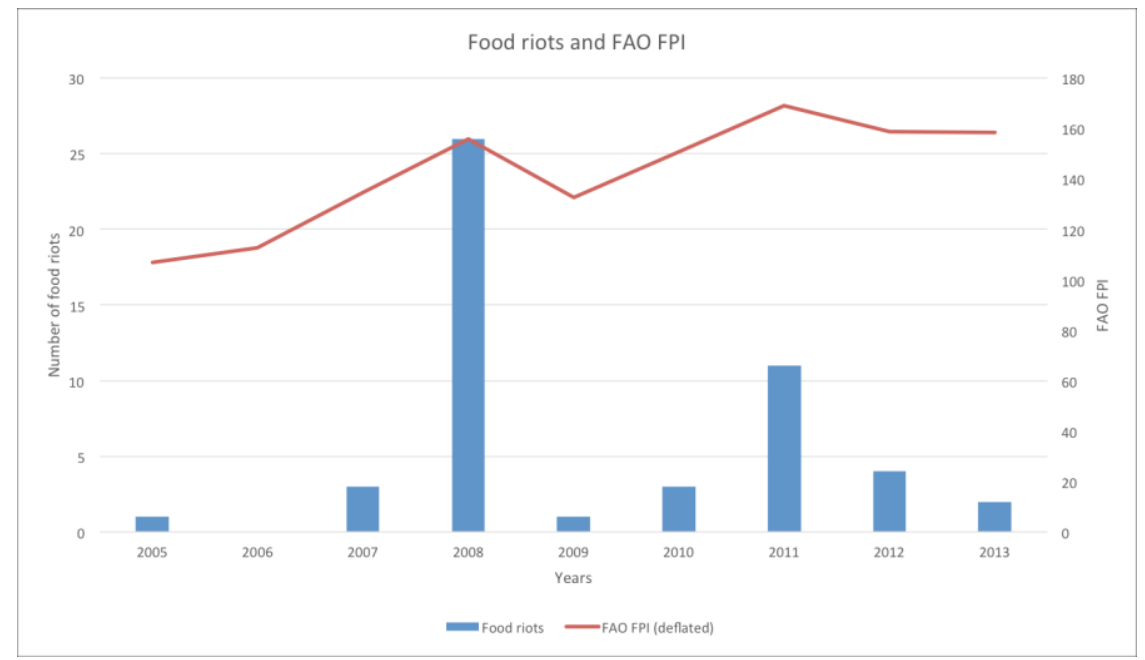

Fig. 2 Plot of the frequency of food riots per year (columns) and of the deflated version of the FAO FPI (red line) for the period $2005-2013$.

Using this new set of data we estimated a logistic random effects model on a panel dataset with all the countries over the timeframe $2005-2013$. As found by Natalini, et al. (2015) the maximum likelihood estimations resulted in a highly significant positive coefficient for the deflated FAO FPI (Table 1). We also recalculated the threshold above which countries start to experience food riots which was 140 , slightly lower than the one found by the authors, but, due to the larger database we have used in this paper, more accurate. More precisely, the 140 threshold represents the deflated FAO FPI value above which the probability for a random country to experience a food riot is $>1 \%$. 


\begin{tabular}{lllll}
\hline (Intercept) & -11.689 & 1.785 & -6.549 & $5.79 \mathrm{e}^{-11 * * *}$ \\
FAO FPI deflated & 0.051 & 0.011 & 4.526 & $6.02 \mathrm{e}^{-06 * * *}$ \\
$\sigma$ & 1.524 & 0.397 & 3.842 & $0.000 * * *$ \\
Log-Likelihood & -217.185 & & & \\
\hline
\end{tabular}

Table 1 Random effects logit regression model estimating the effect of the independent variable 'FAO

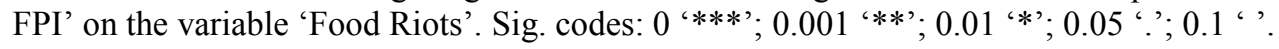

As pointed out in the previous section, food riots do not depend exclusively on the international price of food, but also on other complex dynamics. In particular, Natalini, et al. (2015) found that food riots are more likely to happen in countries that are already highly fragile. In that paper the authors tested different indices of political fragility and found that the index that performed best at predicting food riots was the Political Stability and Absence of Violence from the Worldwide Governance Indicators (WGI) developed by the World Bank (WB, 2015c). Once updated, the authors' database of food riots and a more accurate threshold for the FAO FPI found, we reran their Hazard model to verify whether the WGI still was a good predictor of food riots in countries. For the purpose of this analysis, countries that experienced more than one food riot during the time frame selected have been counted once. The periods when the deflated version of the FAO FPI was above the 140 threshold were the following: i) August 2007-September 2008 that corresponds to 15 months and 27 food riots (as India experienced more than one food riot in the period considered); ii) November 2009 - February 2010 that corresponds to 4 months and no food riots; iii) July 2010 - November 2014 (beyond the period considered for this analysis, so our analysis only considered July 2010 - December 2013) that corresponds to 42 months and 20 food riots. We hence analysed the periods 2007-2008 and 2010-2013 as these were the only timeframes when the FAO FPI was above the threshold and food riots occurred. Since the results from the Hazard model run on both periods were very similar, here we report only those for the period 2010 - 2013. Differently from Natalini et al. (2015) we decided to use national data from the first year (i.e. 2010) rather than data averaged for the two (or more) years, as this is more common practice in the use of Hazard models.

In Table 2 we present the results from the second period, which fundamentally confirm those found by Natalini, et al. (2015). Whether a country is a net cereals importer or exporter does not seem to significantly impact the occurrence of food riots. Conversely, even with a longer period of analysis and a larger food riots database the WGI is a good predictor of food riots in countries and hence we used this measure to calculate the political fragility of the countries in the DGSM. Figure 3 shows the Hazard Ratios for the WGI.

Table 2 Hazard model on the period July 2010 - December 2013 when the deflated version of the FAO FPI was above the 140 threshold using whether the countries were net importers/exporters and WGI as covariates.

\begin{tabular}{lllllll}
\hline Covariates & $\begin{array}{l}\text { Regression } \\
\text { Coefficient }\end{array}$ & $\begin{array}{l}\text { Exponentiated } \\
\text { Coefficient }\end{array}$ & $\begin{array}{l}\text { Standar } \\
\text { d Error } \\
\text { (Coef) }\end{array}$ & $\begin{array}{l}\text { Robust } \\
\text { Standard } \\
\text { Error }\end{array}$ & $\mathbf{z}$ & p-value \\
\hline Importer/exporter & -0.321 & 0.726 & 0.455 & 0.455 & -0.706 & 0.48 \\
WGI 2010 & 0.943 & 2.567 & 0.211 & 0.190 & 4.970 & $6.71 \mathrm{e}^{-07 * * *}$ \\
\hline
\end{tabular}

Notes: $\mathrm{N}=204$; number of events $=20$ (8 observations deleted because they were missing); concordance $=0.769($ se 0.065$) ; \mathrm{R}$-squared $=0.099(\max$ possible $=0.644)$; likelihood ratio test $=$ 21.18 on $2 \mathrm{df} ; p=2.513 \mathrm{e}-05$; Wald test $=27.67$ on $2 \mathrm{df} ; p=9.809 \mathrm{e}-07$; score $(\log$ rank $)$ test $=24.31$ on

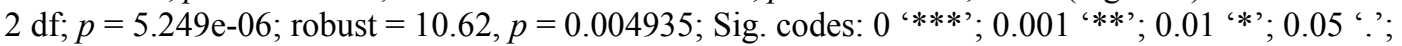
0.1 ' 


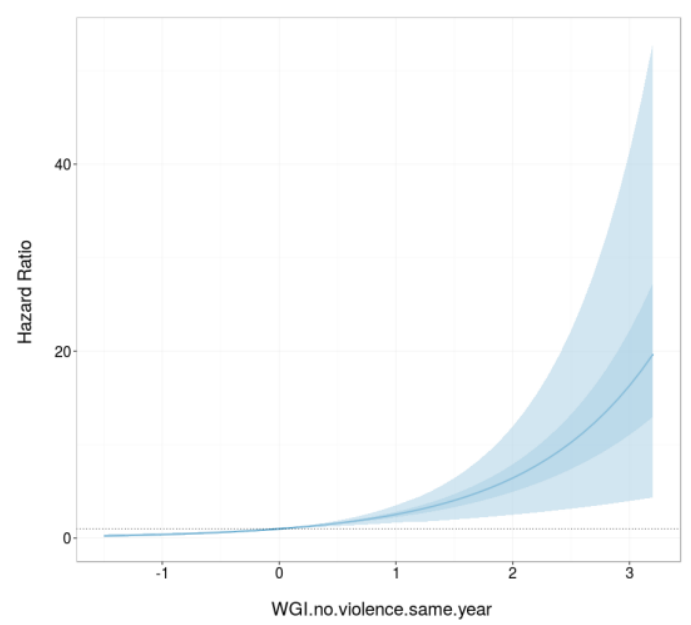

Fig. 3 Plot of the hazard ratios for WGI, where the hazard ratios are plotted on the y-axis and WGI on the x-axis. The shaded areas represent the $\sigma$ and $2 \sigma$ probability intervals, respectively.

\section{The Dawe Global Security Agent-Based Model}

One of the main characteristics of ABMs is the possibility of simulating a system while including interactions between micro (i.e. national, country-level in this case) and macro (i.e. global) levels of analysis. This was particularly important to our research as the system recreated in the model is made of individual agents (countries) whose decisions (in this case production, consumption and trade of food) have international consequences in terms of global availability of cereals and hence international prices, which in turn have national consequences in terms of occurrence of national food riots. The ABM that we present in this paper is empirically grounded, meaning that all the data fed into the model as well as the parameters used have been informed using real data. In particular, we used the updated analysis from Natalini, et al. (2015) presented in the previous section of the paper to inform some of the key dynamics in the DGSM. In particular, in the DGSM the occurrence of food riots mainly depends on the level of the international price of food as estimated by the FAO FPI (i.e. either above or below the 140 threshold) and on the political fragility of countries as estimated by the WGI. Also, the DGSM was built to give short-term (5 years) predictions.

The DGSM is structured around four main elements: i) characteristics of countries; ii) international trade of cereals; iii) international price of food; iv) food riot dynamics. These elements will be introduced individually and then we will provide a brief summary of the dynamics as they occur inside the DGSM.

\subsection{Characteristics of the countries}

In our model each agent represents a country, with 213 countries in total. The model simulation starts in 2005 and we used real data available for that year to inform countries' characteristics. The data that has been used to inform the characteristics of the countries come from the Global Resource Observatory (GRO) project, which holds a collection of data sourced from trusted open-source databases such as the World Bank and the Food and Agriculture Organisation of the United Nations and further manipulated by the researchers from the Global Sustainability Institute to improve consistency and fill in the gaps. The full database is freely available on the institute's website (GSI, 2015). During the period simulated (i.e. the years from 2005 to 2013, which is the latest year for which data is available) three new countries were constituted (i.e. Montenegro in 2006; Kosovo in 2008; South Sudan in 2011) and these countries are added in the model the year after they have been founded using real data for that year.

Projections for consumption and production of cereals for each country have been calculated on real data available for the period $2005-2013$ by fitting polynomial regression trend-lines to the data points available. The production and consumption data are therefore smoothed to provide production and consumption trends in each country. Therefore, significant production shocks are not present in these trends and needed to be added exogenously to the model to recreate real world events where they have occurred (e.g. the 2007/2008 production losses). 
At the beginning of the simulation, countries were also given cereal stocks using data from the GRO database (GSI, 2015). These stocks were replaced at the end of each year with the leftover internal availability of cereals for each country.

Countries were also provided with stock-to-use ratios (SURs), which we kept constant throughout the simulation. These have been calculated for each country by averaging the ratio between stocks and consumption for each year also using data from the GRO database (GSI, 2015).

\subsection{International trade of cereals}

The countries in our ABM are embedded in a social network that recreates international trade of cereals. Real data have also been used to inform these links and have been sourced by the United Nations Comtrade database (UN, 2014). Since the staple that is most traded in the world is wheat, we decided to use data for international trade of wheat as a proxy for cereals traded in the world. A further enhancement of the model would be to explore the main traded crops (wheat, maize, rice and soybean) separately to better model trade links - in particular those within Asia (rice) and those from Latin America (soybean). The links created between countries reflect real international food trade exchanges based on wheat. The network was initialised on data for 2005 and its subsequent evolution was based on the logic of keeping existing links when possible and seeking new ones at random when the supply from existing links became insufficient.

The international trade of cereals has arbitrarily been split into two rounds, the first one with countries importing what they need to cover their current consumption, and the second one to cover their need of restocking (i.e. build up national reserves of cereals). In the first round, following the calculation that decides whether countries are net food importers or exporters, the importing countries use their existing links to find potential exporting countries to trade with and import $10 \%$ of what they need from each of them. This is to avoid depletion of a country's stock by one single country. If their current pool of partners cannot meet the importing country's cereals demand, then they will select a random country they don't already have a link with that still has cereals stocks available and import from it. This procedure continues until either the import needs for each country are satisfied or until the exports available in the world are finished.

Before the second round of exchanges, countries compute their desired cereal stock by multiplying their SUR for their consumption and use their leftover internal availability of cereals to satisfy this. If not sufficient, countries will import what they need from the other countries following the same procedure as during the first round. This procedure continues until either the restocking needs for each country are satisfied or until the exports available in the world are finished.

\subsection{International price of food and food riots}

Based on the research from Natalini, et al. (2015) and our updated results we included international food price dynamics in the model as two regimes, either above or below the threshold of 140. This decision was also due to the aim of the model being not to recreate the perfect formation of the FAO FPI, but rather to include as many conditions necessary for the model to reproduce the occurrence of food riots in countries as possible.

The model was calibrated using the real series of world food prices, which showed a below-threshold level from 2005 to 2007, a first spike above the threshold in 2008, a return of the prices below the threshold in 2009, and finally four consecutive years above the threshold from 2010 to 2013 . The aim of the calibration was to reproduce this series using the model data for global production, consumption and stocks of food and real data for international food price regimes (i.e. either above or below the threshold). It is worth noting here that the aim of the DGSM was not to investigate and model the formation of international prices, rather to model some of the dynamics that lead to the occurrence of food riots. Although the presence of an international price for food is essential in the DGSM at its current stage of development, the dynamics of price formation are not and have therefore been simplified.

For the calibration of international food prices, an Evolutionary Tree (ET) model was fit to the data from the model using the ratio between Global Cereals Production and Global Cereals Consumption and Global Cereals Stocks as independent variables and the real series of price regimes between 2005 and 2014 as target variable. The was implemented using the R package evtree (Grubinger, et al., 2014) and the results are presented in Figure 4. 


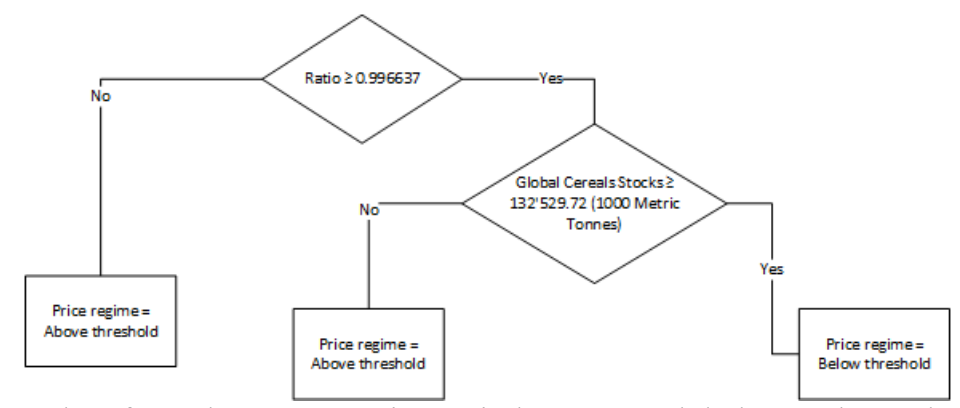

Fig. 4 ET model on data from the DGSM using ratio between 'Global Cereals Production' and 'Global Cereals Consumption' and the variable 'Global Cereals Stock' as independent variables and the variable 'Price threshold' as target variable.

The results from the ET perfectly recreate the international price regime for the period considered and show intuitive dynamics between the trends in global ratio and stocks for cereals and international price regime. In particular, when the ratio between global production and consumption of cereals is smaller than 0.996637 , the international price of food is above the threshold. For any ratio larger or equal to 0.996637 , global stocks of cereals become significant and, in particular, when these are smaller than 132,529.72 (1000 MT), the price climbs above the threshold, and below otherwise.

\subsection{Food riot dynamics}

To translate the findings from Natalini, et al. (2015) and our updated results in a format that could be used as dynamics in the ABM and to further test whether the international price of food (as captured by the FAO FPI) and the fragility of a country (as estimated by the WGI) are significant variables in determining whether a country is more likely to experience a food riot, we used a Regression Tree Random Effects Model provided by the R package REEMtree (Sela and Simonoff, 2011). This instrument is highly recommended when trying to find patterns or categories in given variables and implement the findings in an ABM (Sánchez-Maroño, et al., 2015). We added two new discrete variables to our database, one that classifies each record either below or above the 140 price threshold and another that divides the countries into four homogenous categories of fragility (i.e. high, mediumhigh, medium-low, low) according to their WGI estimate for each year. We then ran the REEMtree model using the variable food riots as dependent and the two newly created discrete variables as independent to find different combinations of price regime and fragility that lead to different probabilities for countries to experience food riots. The results of the model are presented in Figure 5.

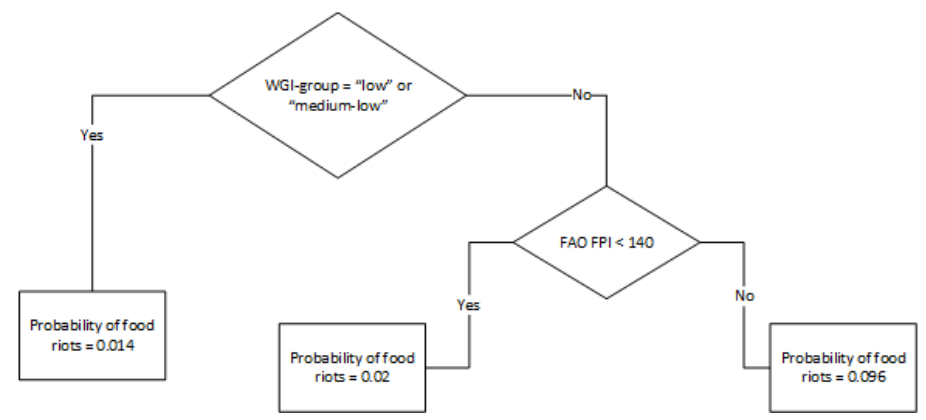

Fig. 5 REEM model for FAO FPI threshold and WGI categories. Notes: $n=1904$; intercept $=1.08 \mathrm{e}^{-04}$; Estimated variance of errors $=0.03$; Log likelihood $=789.55$.

The model assigns a basic probability of experiencing a food riot (i.e. the intercept) which is the same for all the countries (and that, in our case, was very close to zero). In addition the model provides probabilities according to different combinations of the values for the independent variables: the estimates showed that both variables were significant in determining whether a country will experience a food riot or not. In particular, countries with low and medium-low fragility have the same probability of experiencing a food riot, whereas countries in the more fragile categories have a different probability depending on whether the price is above or below the threshold. The model also assigns to each country a unique probability of experiencing a food riot (i.e. the random effects) that can be found in Appendix 2. The final probability for each country to experience a food riot is thus the sum of the intercept, the probability resulting from the tree combinations of fragility and price and random effects. 
To implement the findings from this section in the ABM, we needed to provide an estimate for the WGI for each country. Since this index is an agglomerate of several different indices and measures (WB, 2015b), it could not be recreated endogenously. This is also because the purpose of modelling is to better understand one or more dynamics of the real world, often too complex to be comprehended by simply observing the system. It is hence essential to isolate the conditions for that dynamic to happen and simulate only those. Failing to do so might result in a model that is too complex to understand hence defeating the original purpose of modelling itself. For this reason we used the same approach used to simulate the production and the consumption of food for each country, simply by fitting trend lines to the data points we had available for the WGI estimates for each country for each year over the period $1995-2013$.

\subsection{Introducing exogenous production shocks}

As trend lines were used to calculate the production function within the DGSM, we required exogenous production shocks to be reintroduced in the model exogenously. These production shocks were derived from real world data. In particular, a significant price shock was observed in 2007/08 in global food as depicted in Figure 6.

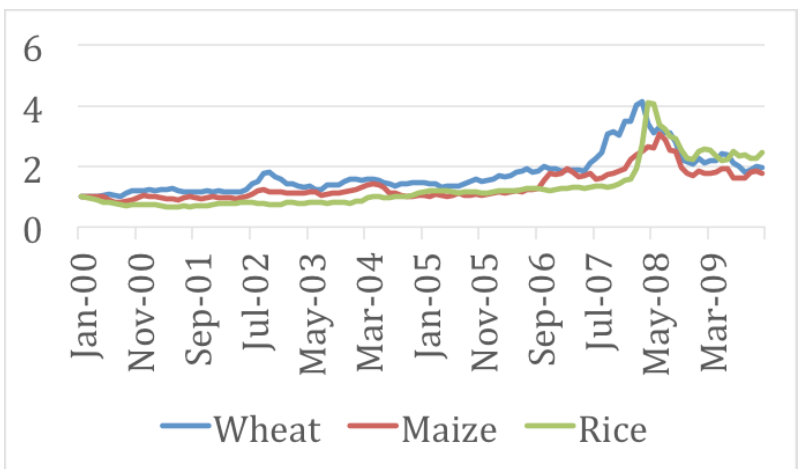

Fig. 6 Monthly prices for 2000-2010 for wheat, maize and rice showing significant price shocks in 2007/08. Prices are normalised so that price for each grain in January 2000 is 1.

Food production around this time was significantly impacted by several factors (Challinor, et al., 2015). However, two major food production shock events occurred before the price shock of 2007/08 in 2002/03 and 2006. During 2002/03 food stocks globally were at an all-time high. This was mainly due to high stock levels in China and the production shock happened to coincide with the time when China had decided to strategically reduce its stock levels. Therefore, this food production shock was delayed as stocks entered international trade. The impact of the food stock reduction and production shocks in 2002/2003 and 2006 (along with political responses to these events) is widely credited with causing the food price spikes in 2007/2008 (Headey and Fan, 2010). We therefore took the average food production shock in the major food producing countries as our basis for our exogenous shock.

To calculate the food production shocks in 2002, 2003 and 2006 we first fit best fitted lines per country to production data between 2000 and 2013 for the major grains (wheat, maize and rice) (Jones and Phillips, 2016). This was done for each of the main country producers of those three grains, which represented $75 \%$ of global production. These best fit lines were then subtracted from production to remove the overall growth in production which characterised the food system. This growth matched the increase in demand from changing diets and a growing population. A percentage anomaly per year per country was then calculated away from this best fit line by dividing by the production for that country. Table 3 shows these country anomalies for each year and the average for the years 2002, 2003 and 2007. These average production shocks were then taken to create our best estimate of the cumulative size of the production shock that caused the food price shock in 2007/08. The sum of these production shocks represented an overall global food production shock of $8 \%$.

Table 3 Food production anomaly (percentage of overall production) away from best fit line for the three major grains (wheat, maize and rice) between 2000 and 2010 in major food producing countries. The average losses per country for the major production shock events (2002, 2003 and 2006) are shown in the final column. 


\begin{tabular}{|l|l|l|l|l|l|l|l|l|l|l|l|l|}
\hline & & & & & & & & & & & & shock \\
\hline Argentina & 4 & 1 & $\mathbf{- 3}$ & $\mathbf{- 1}$ & 0 & 2 & $\mathbf{- 3}$ & 6 & -3 & -12 & 5 & $\mathbf{- 3}$ \\
\hline Australia & 4 & 6 & $\mathbf{- 1 0}$ & $\mathbf{7}$ & 2 & 5 & $\mathbf{- 1 1}$ & -9 & -1 & -1 & -1 & $\mathbf{- 5}$ \\
\hline Bangladesh & 3 & 0 & $\mathbf{0}$ & $\mathbf{0}$ & -4 & -2 & $\mathbf{- 2}$ & -1 & 1 & 1 & 2 & $\mathbf{- 1}$ \\
\hline Brazil & 0 & 8 & $\mathbf{- 1}$ & $\mathbf{9}$ & -1 & -12 & $\mathbf{- 7}$ & 1 & 5 & -7 & -5 & $\mathbf{0}$ \\
\hline Canada & 6 & -1 & $\mathbf{- 6}$ & $\mathbf{0}$ & 2 & 2 & $\mathbf{1}$ & -6 & 3 & 0 & -5 & $\mathbf{- 2}$ \\
\hline China & 36 & 13 & $\mathbf{- 1}$ & $\mathbf{- 4 0}$ & -13 & -10 & $\mathbf{2}$ & -6 & 4 & -6 & -5 & $\mathbf{- 1 3}$ \\
\hline France & 3 & -4 & $\mathbf{4}$ & $\mathbf{- 6}$ & 4 & 1 & $\mathbf{- 1}$ & -4 & 2 & 1 & 1 & $\mathbf{- 1}$ \\
\hline Germany & 0 & 1 & $\mathbf{- 1}$ & $\mathbf{- 3}$ & 3 & 1 & $\mathbf{- 1}$ & -2 & 3 & 2 & 0 & $\mathbf{- 2}$ \\
\hline India & 18 & 19 & $\mathbf{- 2 0}$ & $\mathbf{- 2}$ & -11 & -6 & $\mathbf{- 9}$ & 2 & 4 & -16 & -7 & $\mathbf{- 1 0}$ \\
\hline Indonesia & 4 & 1 & $\mathbf{0}$ & $\mathbf{- 1}$ & -1 & -2 & $\mathbf{- 4}$ & -3 & -1 & 2 & 2 & $\mathbf{- 1}$ \\
\hline Pakistan & 2 & 0 & $\mathbf{- 2}$ & $\mathbf{- 1}$ & -1 & 1 & $\mathbf{0}$ & 1 & -2 & 1 & 0 & $\mathbf{- 1}$ \\
\hline Russia & -11 & 4 & $\mathbf{9}$ & $\mathbf{- 1 1}$ & -1 & 1 & $\mathbf{- 2}$ & 5 & 17 & 15 & -19 & $\mathbf{- 1}$ \\
\hline Thailand & 0 & 1 & $\mathbf{0}$ & $\mathbf{1}$ & -1 & 0 & $\mathbf{- 2}$ & 0 & -1 & -2 & 0 & $\mathbf{0}$ \\
\hline Ukraine & 0 & 9 & $\mathbf{7}$ & $\mathbf{- 1 1}$ & 4 & 1 & $\mathbf{- 8}$ & -9 & 6 & -3 & -8 & $-\mathbf{4}$ \\
\hline USA & 14 & -13 & $\mathbf{- 4 6}$ & $\mathbf{- 1}$ & 32 & 4 & $\mathbf{- 2 9}$ & 39 & 18 & 29 & 4 & $\mathbf{- 2 5}$ \\
\hline Vietnam & 1 & 0 & $\mathbf{1}$ & $\mathbf{0}$ & 1 & 0 & $\mathbf{- 1}$ & -2 & 0 & -1 & -1 & $\mathbf{0}$ \\
\hline
\end{tabular}

\subsection{Summary of the dynamics included in the DGSM}

To further clarify the sequence of the processes that countries included in the DGSM go through, we provide a brief summary of one run of the simulations. The simulation starts with countries producing and consuming cereals, and countries compute whether they are net cereals exporters or importers by adding their current production to their stocks from the previous year and then subtracting their own current consumption. The leftover cereals available are summed to obtain a global figure of cereal availability and national consumptions are also summed to obtain a figure for global cereal consumption. According to these global figures and two parameters calculated through the calibration of the model, the international price of food is set either above or below the 140 FAO FPI threshold. Countries subsequently trade to cover both their leftover consumption and need for stocks of cereals. They then calculate their level of political fragility as given by the WGI. According to this estimate, the international price of food and to their own probability of experiencing food riots, they will have different probabilities of experiencing a food riot that year. At the end of the year, the leftover cereals become national stocks that will be carried over to the next year. This process is repeated each year.

\subsection{Validation of the DGSM}

Models that aim at producing meaningful predictions for future events need to be validated, also to facilitate their replicability (Squazzoni, 2012). As mentioned before, the DGSM is empirically grounded, which means that we used real data to generate the characteristics of the countries and we informed parameters and relationships with statistical and econometric tests carried out on real data from past events. This means that the model is internally validated (Squazzoni, 2012). To further test whether the dynamics included in the DGSM were sufficient to recreate the occurrence of food riots we analysed the data produced from the model in the period 2005 - 2013 and compared it with the real data on food riots presented in Section 2.

In order to validate the DGSM, 100 simulations were run and analysed. Firstly, the simulated cumulative probability of food riots to happen in the years below (i.e. $2005-2007$ and 2009) and above (2008 and 2010 - 2013) the 140 FAO FPI threshold were calculated and compared with the real cumulative probability during those periods. The simulated probability for the below-threshold period was 0.06 whereas the real probability was 0.02 . For the above-threshold period, the simulated probability was 0.17 , whereas the real probability was 0.22 . Although the DGSM overestimates countries' probability to experience a food riot when the international price of food is below the threshold and underestimates their probability when the price is high, the probabilities are remarkably similar when aggregated by price regime.

Figure 7 plots the number of food riots per year as they occurred in reality and as predicted by the DGSM, alongside the confidence interval for the simulated results. The 2008 peak plotted in both lines 
is proof that the $\mathrm{ABM}$ correctly represents a higher probability of the occurrence of food riots in that year, and, although the absolute number of food riots per year is underestimated by the model, the lines follow the same pattern. Interestingly, the model failed to fully capture the second peak of food riots that occurred in 2011 and tended instead to spread the riots that occurred in 2011 over a four-year period also covering 2010, 2012 and 2013.

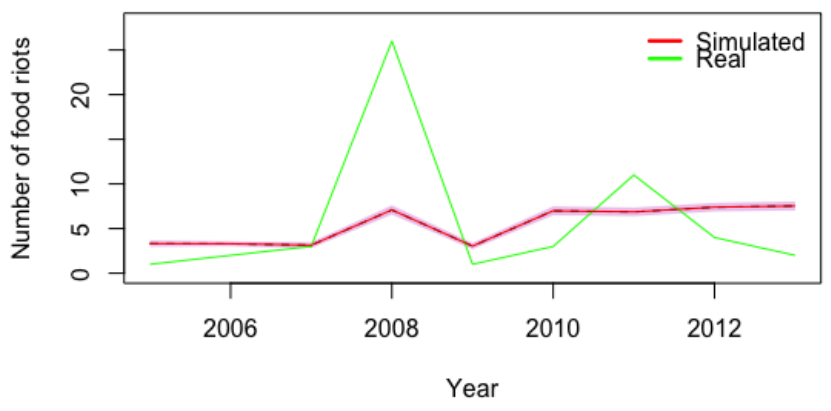

Fig. 7 Number of food riots per year as they were reported and as predicted by the DGSM. The pink highlighted area around the red line (model's results) represents the 95\% confidence interval in the model's results.

To further investigate the results from the DGSM, the list of countries with the highest probability of food riots throughout the whole period as simulated in the model and the database of food riots presented in Section 3 were compared to evaluate the accuracy of the DGSM at predicting which countries experienced food riots in the time frame considered. The simulated probabilities ranged between $0 \%$ and $9 \%$ with the lowest probability assigned to Australia and the highest to India. In particular, $70 \%$ of the countries that fell within the top 10 countries most at risk of experiencing a food riot as calculated by the DGSM experienced a food riot. This percentage remains unvaried for the top 20 countries most at risk and $63 \%$ for the top 40 .

The accuracy of the DGSM was investigated further by evaluating the predictions for both year and country for each food riot resulting from the ABM simulations. In order to do this, an R (R Core Team, 2013) script calculating the percentage match between real and simulated food riots was run. The script first calculated the overall accuracy of the model (i.e. at predicting both countries that did experience a food riot during a given year and countries that did not), the percentage of correctly predicted food riots in each country for each year and finally the percentage of false food riots predicted (i.e. food riots predicted by the model in a certain country during a given year that did not occur in reality). This was done for each of the 100 runs of the DGSM and the average results are presented in Table 4.

Table 4 Summary of the averaged results for the predictions from the 100 runs of the DGSM, where Food.all is the overall accuracy of the model at predicting both countries that did and did not experience a food riot in reality, Food.true the percentage of correctly predicted food riots in each country for each year and Food.false is the percentage of false food riots predicted.

\begin{tabular}{ll}
\hline Variables & $\begin{array}{l}\text { Percentages } \\
\text { predicted }\end{array}$ \\
\hline Food.all & $95.13 \%$ \\
Food.true & $6.86 \%$ \\
Food.false & $2.44 \%$ \\
\hline
\end{tabular}

The validation based on the probabilities per year show that the model captures important dynamics that cause food riots at the larger scale, although underestimating the total number of food riots per price regime. In addition, the analysis on countries that are predicted to experience a food riot at any point during the time frame considered led to remarkably accurate results. However, the validation on the DGSM's predictions for year and country for each food riot show that the model is not fully able to capture the specific year during which each country experiences a food riot and can hence be 
improved. It is worth noting here that the DGSM, similarly to any other computer model, is not aimed at giving (cannot provide) precise predictions about which country will experience a food riot and when, but rather it is aimed at giving an indication about which countries are at risk of social upheavals due to multiple factors, amongst which we find a high international price of food and their political fragility. Further developments of the model may hence include a broader range of influencing factors along with revised internal dynamics to fully capture internal feedback effects. These updates to the model will be explored in more detail in the Conclusions Section.

\section{Forecasting 2017 food riots}

In order to provide forecasts for the future of food riots, 100 simulations of the DGSM were run and the results for food riots for the year 2017 were analysed. This year was selected because it is the first year in the future at the time of writing this paper (i.e. March 2016) and, in addition, the ABM was built to provide short term forecasts for the $5-10$ years after the last year used to calibrate the models, which in this case was 2013.

The results from the DGSM for the international price regimes suggest that both food and fuel price are likely to be above the threshold in 2017 , thus increasing the probability of the occurrence of food and fuel riots during this year. However, the predictions for the international price regime need to be taken with reservations as mentioned in Section 3.3.

Out of all the years considered, 2017 had one of the highest probability for a random country to experience a food riot, which was around $4 \%$ as compared to $1 \%$ in 2005 (i.e. the year with the simulated lowest probability of food riots) and 3\% in 2008 (i.e. the year that registered the largest number of food riots in reality). The probabilities of food riots for countries for the year 2017 ranged between $0 \%$ and $17 \%$, with the highest probability assigned to Turkey. In the top 10 countries most at risk we find Turkey, Afghanistan, Cameroon, Congo Democratic Republic, Iran, Lao, Thailand, Algeria, Mauritania and Nigeria, with probabilities spanning between $17 \%$ and $13 \%$. 30 countries were assigned with the lowest probability, amongst these we find Austria, Belgium and Iceland. For a better visualisation, the results from the food riots forecast for 2017 from the DGSM are presented in Figure 8 .

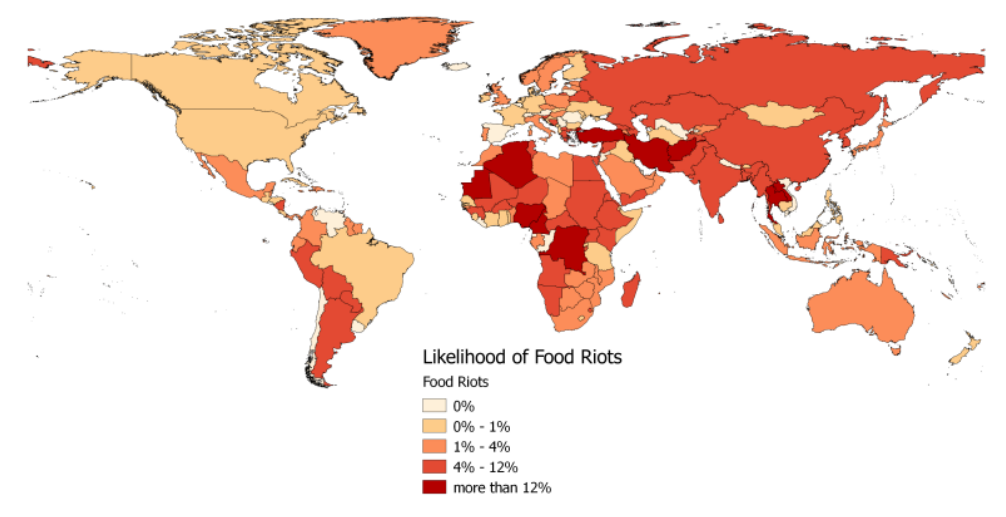

Fig. 8 Probability of food riots for countries based on the forecast for 2017 from the DGSM.

The countries that top the list with the largest forecast probability of experiencing a food riot in 2017 differ for their political situation and with regard to their history of food riots. The four main variables that define the probability for a country to experience a food riot are: i) the intercept identified by the REEMtree model (equal for all countries); ii) whether the FAO FPI is above the threshold (equal for all countries); iii) the WGI group of fragility for the country and iv) the country-specific random-effects assigned by the REEMtree model based on a country's history of food riots. The intercept and randomeffects assigned by the REEMtree model are very small, which means that, realistically, the only factors having a prominent effect on countries' probabilities for food riots are the price regime (either above or below the 140 threshold) and a country's WGI group. As mentioned above, to limit the complexity at this stage of development of the model, countries' estimates for the WGI are calculated according to the trend lines calculated on data available between 1995 and 2013. The countries that top the list of probability of food riots for 2017 all show an increasing trend in the data for the WGI in the period considered. Therefore, the trend lines applied to the data result in high WGI estimates for these countries in 2017. It is worth reminding at this point that the WGI is an aggregated index of political fragility of countries, which summarises the information for several different variables and expert opinions, as listed in WB (2015b). Finally, the FAO FPI is forecast to be above the threshold for 2017, 
hence causing the probability of countries with high levels of fragility to increase significantly (see Figure 5). These reasons explain the diversity between the countries that top the list of probability of food riots for 2017.

\section{Conclusions}

Global food security is increasingly becoming a concern for the international policy arena, particularly because of the possible consequences of climate-related extreme events that can negatively affect the production of food in some key regions of the world. Due to the high interconnectedness of the global food system, such production shocks can have negative impacts on international economy and political fragility of countries, making this subject worth further investigation using a systemic approach. The transmission from production shocks to instability via prices supposedly occurs through national subsidies for food prices. Indeed, some authors argue that another main cause of food riots, particularly during the 2008 global food crisis, was the effective or prospected removal of food subsidies (Brinkman and Hendrix, 2011). The newspaper articles gathered to compile the databases of food and fuel riots used in this research often mentioned as one of the causes of the violent protests either the effective or threatened removal of food subsidies. Developed, developing and low-income countries normally subsidise the prices of food and energy resources to ensure their affordability, especially when the prices increase (IMF, 2008; Hendrix, et al., 2009). However, these constitute an onerous expenditure when the price of imported goods spikes, especially for poor countries. It is hence credible to believe that once the price of food crosses a certain threshold due to either a food production shock or a disruption in the international food supply chain, poor countries decide to cut subsidies, causing grievances from the populations which can turn into (food) riots. This threshold is set at 140 for the deflated, annual version of the FAO FPI, as found in this paper. Our findings also confirm that, as previously found by Natalini, et al. (2015), national food security does not significantly impact the occurrence of food riots as opposed to international food prices and national political fragility.

In this paper we also present a first attempt to model the complexity of the global food system, focussing on global food availability, international trade of cereals, the interaction with international price of food and the rise of social conflict, mainly in the form of food riots. We developed an AgentBased Model (ABM) called the Dawe Global Security Model (DGSM) to simulate the complex dynamics of the system, also providing forecasts for food riots for the year 2017.

The validation of the model shows that the DGSM is able to capture the general conditions that cause food riots to occur. In particular, the model results show a good level of accuracy whilst predicting probability of riots when the price is above/below the threshold and for countries' probability of experiencing a food riot at any point during the time frame considered. The DGSM forecast an international food price regime above the threshold for the year 2017 and identified Turkey, Afghanistan, Cameroon, Congo Democratic Republic, Iran, Lao, Thailand, Algeria, Mauritania and Nigeria as the countries most at risk of food riots. As highlighted before, the DGSM cannot provide precise predictions for which countries will experience a food riot in the future. Its forecasts should be used as an indication as to which countries require further attention and more in-depth research on critical national fragilities. Indeed, whether a country will experience a food riot depends on a long list of different factors, most of which still have to be identified, and on the governments' responses to such criticalities. The model can, however, be used to identify some of these criticalities, such as countries' political fragility, their history of food riots and the international food price regime.

The findings from our quantitative and simulation studies seem to indicate that national food insecurity does not directly translate in that country's higher probability of food riots. Rather, our model simulates how national food production shocks (i.e. food insecurity) can result in a spike in the international price of food, which in turn can cause food riots in countries far from where the crisis originated. This reasoning fits with the increasingly accepted acknowledgment that food security, and, more in general, scarcity of natural resources, is not a direct cause of conflict, but rather a stressor or catalyst (e.g. Homer-Dixon, 1999; OECD, 2012; Raleigh, et al., 2015). As highlighted by our results presented in Section 3, the political fragility of countries is a critical factor in the evaluation of countries' probability for experiencing food riots, which is in line with current literature (e.g. Natalini, et al., 2015; Brinkman and Hendrix, 2011). Commenting on our findings in the wider context of the 2008 global food crisis, the results from our research support the analysis that the crisis was caused by multiple stressors and that connected different socio-ecological systems, namely the food, energy and finance sectors (Homer-Dixon, et al., 2015). Food insecurity is indeed portrayed by Homer-Dixon, et al. (2015) as only one of the several factors that caused the crisis seen in the food socio-ecological 
system in 2008, which was facilitated by the high (and increasing) interconnectivity and synchronisation of the system. Synchronous failures are forecast to become more frequent in the future, which is why our research on empirical simulation of the food system is more relevant than ever.

This said, further developments are needed to reduce the current underestimation of the total number of food riots per year when a shock occurs and improve the prediction accuracy at the country level. The validation and analysis of the results from the DGSM suggested several potential directions for further research. Firstly, the underestimation of the number of food riots is probably due to the fact that the causes of food riots can be several and varied, ranging from a wider economic distress of a country, to problems in the internal redistribution of food and also the interaction with other political, social and economic situations. However, the statistical predictors for food riots currently included in the model are limited to the price of food and the political fragility of countries. To improve the accuracy of the model, future versions could disaggregate the category 'cereals' in the different main grains and focus on diets. This broad category could conceal great variability, as different grains are key staples for different countries. Populations may be more or less willing to riot according to what grain is scarce or too expensive. In addition, the model currently only includes a threshold on the absolute level of food prices, which identifies both years with high and low numbers of food riots. Future versions of the model could focus on price variations, which may be able to identify the years with the largest number of food riots with more accuracy.

Secondly, as for the prediction of food riots in the correct countries, the model at the moment only distinguishes between countries according to four categories of political fragility, which are rather wide. The only instrument included in the model that differentiates one country from another in terms of probability of food riots is the country-specific random effects estimated by the REEMtree model, which have a relatively minor impact on the overall probability of riot due to the low number of violent food riots.

A third possibility to improve the model performance is linked to the fact that, in its current version, the occurrence of food riots in countries does not have any consequence on other variables. In future versions of the model, further consequences of countries that experience food riots could be explored. This has been observed in countries such as Syria where rioting, which was one of the causal triggers in food protests, escalated into civil war, thereby having significant impact on food production. Another possible improvement to the model is to further investigate the causes that led each country to experience a food riot, or, more simply, refine how the political fragility is calculated in the model, maybe translating it in an endogenous process.

Finally, the model does not currently exploit the ABM capabilities to the fullest. In particular, the possibility of creating emergent properties generated by the interaction between the countries and their individual decisions is limited by the trend lines that define their production and consumption. In future versions of the model, countries could make decisions based on their populations and other social or economic variables in terms of consumption and production of food, hence changing the dynamics of the model.

\section{Conflict of interest}

The authors declare that they have no conflict of interest.

\section{References}

Aburawa, A. (2011, January 13, 2011). Rising food prices behind riots in algeria and tunisia. Green Prophet

Aljazeera. (2011, February 27, 2011). Deaths in oman protests. Aljazeera

Al-Salhy, S. (2011, February 3, 2011). Iraquis protest power and food shortages; 3 shot. Reuters

Anderson, K. (2010). Globalization's effects on world agricultural trade, 1960-2050. Philosophical Transactions of the Royal Society of London.Series B, Biological Sciences, 365(1554), 3007-3021. doi:10.1098/rstb.2010.0131

Arezki, R., \& Bruckner, M. (2011). Food prices and political instability. Unpublished manuscript. 
Arsenault, A., Nolan, J., Schoney, R., \& Gilchrist, D. (2012). Outstanding in the field: Evaluating auction markets for farmland using multi-agent simulation. Journal of Artificial Societies and Social Simulation, 15(1), 11. doi:10.18564/jasss.1827

Asian Correspondent. (2013, November 11, 2013). Food, climate change and war: The syria crisis. Asian Correspondent

Auyero, J., \& Moran, T. P. (2007). The dynamics of collective violence: Dissecting food riots in contemporary argentina. Social Forces, 85(3), 1341-1367. doi:10.1353/sof.2007.0030

Bailey, R., Benton, T. G., Challinor, A., Elliott, J., Gustafson, D., Hiller, B., Jones, A., Jahn, M., Kent, C., Lewis, K., Meacham, T., Rivington, M., Robson, D., Tiffin, R., Wuebbles, D. J. (2015). Extreme weather and resilience of the global food system. final project report from the UK-US taskforce on extreme weather and global food system resilience. London: The Global Food Security Programme.

Barbet-Gros, J., \& Cuesta, J. (2014). Food riots: From definition to operationalization. Unpublished manuscript.

Bastardie, F., Nielsen, J. R., Andersen, B. S., \& Eigaard, O. R. (2010). Effects of fishing effort allocation scenarios on energy efficiency and profitability: An individual-based model applied to danish fisheries. Fisheries Research, 106(3), 501-516. doi:10.1016/j.fishres.2010.09.025

Bates, R. H. (2011). Food price shocks and political instability. Washington DC: USAID CMM.

BBC News. (2005, April 1, 2005). Refugee killed in burundi riot. BBC News

BBC News. (2008, April 2, 2008a). Riots prompt ivory coast tax cuts. BBC News

BBC News. (2008, December 15, 2008b). Egypt court convicts food rioters. BBC News

BBC News. (2011, May 1, 2011). Maldives rocked by protests against president nasheed. BBC News

Bellemare, M. F. (2014). Rising food prices, food price volatility, and social unrest. American Journal of Agricultural Economics, 96(4), 1-21. doi:10.1093/ajae/aau038

Berazneva, J., \& Lee, D. R. (2013). Explaining the african food riots of 2007- 2008: An empirical analysis. Food Policy, 39, 28-39. doi:10.1016/j.foodpol.2012.12.007

Berger, T. (2001). Agent-based spatial models applied to agriculture: A simulation tool for technology diffusion, resource use changes and policy analysis. Agricultural Economics, 25(2-3), 245-260. doi:10.1111/j.1574-0862.2001.tb00205.x

Bleischwitz, R., Johnson, C. M., \& Dozler, M. G. (2014). Re-assessing resource dependency and criticality. linking future food and water stress with global resource supply vulnerabilities for foresight analysis. European Journal of Futures Research, 2(1), 1-12. doi:10.1007/s40309-0130034-1

Bozorgmehr, S., Levs, J., \& Sterling, J. (2012, October 4, 2012). Riot police swarm antiahmadinejad protesters in fury over currency. $\mathrm{Cnn}$

Brinkman, H., \& Hendrix, C. S. (2011). Food insecurity and violent conflict: Causes, consequences, and addressing the challenges. Unpublished manuscript.

Buhaug, H., Benaminsen, T. A., Sjaastad, E., \& Theisen, O. M. (2015). Climate variability, food production shocks, and violent conflict in sub-saharan africa. Environmental Research Letters, 10(12), 1-12. doi:10.1088/1748-9326/10/12/125015 
Calzadilla, A., Rehdanz, K., \& Tol, R. S. (2011). Water scarcity and the impact of improved irrigation management: A computable general equilibrium analysis. Agricultural Economics, 42(3), 305-323. doi:10.1111/j.1574-0862.2010.00516.x

Challinor, A., Elliott, J., Kent, C., Lewis, K., \& Wuebbles, D. (2015). Resilience taskforce subreport annex A - climate and global crop production shocks. (). London: The Global Food Security Programme.

Christie, M., Valme, J., \& Briand, X. (2008, April 12, 2008). Haiti's government falls after food riots. Reuters

Coble, K. H., Heifner, R. G., \& Zuniga, M. (2000). Implications of crop yield and revenue insurance for producer hedging. Journal of Agricultural and Resource Economics, 432-452.

Crawley, A., Gethings, D., Lee, J., Marktanner, M., \& Noiset, L. (2012). The rise of food prices and the fall of nations. Unpublished manuscript.

Daily Mail UK. (2012, December, 2012). President resigns after riots leave 22 dead in argentina. Daily Mail UK

Demarest, L. (2014). Food price rises and political instability: Problematizing a complex relationship. European Journal of Development Research, 27(5), 650-671. doi:10.1057/ejdr.2014.52

Devereux, S., \& Maxwell, S. (2001). Food security in sub-saharan africa. London: ITDG Publishing. Filatova, T., Parker, D., \& Van der Veen, A. (2009). Agent-based urban land markets: Agent's pricing behavior, land prices and urban land use change. Journal of Artificial Societies and Social Simulation, 12(1), 3.

Filatova, T., Verburg, P. H., Parker, D. C., \& Stannard, C. A. (2013). Spatial agent-based models for socio-ecological systems: Challenges and prospects. Environmental Modelling \& Software, 45, 1-7. doi:10.1016/j.envsoft.2013.03.017

Gaub, F. (2012). Understanding instability: Lessons from the arab spring. Swindon, UK: Arts and Humanities Research Council.

Gilbert, N. (2008). Agent-based models. Los Angeles, LA: Sage Publications.

Gilbert, N., \& Terna, P. (2000). How to build and use agent-based models in social science. Mind \& Society, 1(1), 57-72. doi:10.1007/BF02512229

Godfray, H. C., Beddington, J. R., Crute, I. R., Haddad, L., Lawrence, D., Muir, J. F., . . Toulmin, C. (2010). Food security: The challenge of feeding 9 billion people. Science, 327(5967), 812-818. doi:10.1126/science.1185383

Goldstone, J. A. (2011). Understanding the revolutions of 2011: Weakness and resilience in middle eastern autocracies. Foreign Affairs, 90, 8-16.

Grubinger, T., Zeileis, A., \& Pfeiffer, K. (2014). Evolutionary learning of globally optimal trees ( $R$ package)

GSI. (2015). The global resource observatory database v2

Headey, D., \& Fan, S. (2010). Reflections on the global food crisis: How did it happen? how has it hurt? and how can we prevent the next one? Intl Food Policy Res Inst.

Healy, B., \& Munckton, S. (2008, April 19, 2008). Global food crisis: Biofuels threaten hunger. Green Left Weekly 
Hendrix, C., \& Brinkman, H. (2013). Food insecurity and conflict dynamics: Causal linkages and complex feedbacks. Stability: International Journal of Security and Development, 2(2), Art. 26. doi:10.5334/sta.bm

Hendrix, C., Haggard, S., \& Magaloni, B. (2009). Grievance and opportunity: Food prices, political regime, and protest. Paper presented at the International Studies Association Convention, New York, NY.

Homer-Dixon, T. (1999). Environment, scarcity, and violence. Princeton, NJ: Princeton University Press.

Homer-Dixon, T., Walker, B., Biggs, R., Crépin, A., Folke, C., Lambin, E. F., Peterson, G. D., Rockström, J., Scheffer, M., Steffen, W. (2015). Synchronous failure: The emerging causal architecture of global crisis. Ecology and Society, 20(3), 6. doi:10.5751/ES-07681-200306

Huang, H., von Lampe, M., \& van Tongeren, F. (2011). Climate change and trade in agriculture. Food Policy, 36(Supplement 1), S9-S13. doi:10.1016/j.foodpol.2010.10.008

IMF. (2008). Fuel and food price subsidies: Issues and reform options. Washington, DC: International Monetary Fund.

IRIN News. (2008, 2 May, 2008). AFGHANISTAN: Coordinated action key to avoiding food tragedy - WFP. IRIN News Asia

Jones, A. W., \& Phillips, A. (2016). Historic food production shocks: Quantifying the extremes. Sustainability, 8(427). doi:10.3390/su8050427

Joy, E. (2012, September 28, 2012). Malawi: Facing the costs of food insecurity and rising prices. Think Africa Press

King, D., Schrag, D., Dadi, Z., Ye, Q., \& Ghosh, A. (2015). Climate change: A risk assessment. (). Cambridge, UK: CSaP.

Kron, J. (2011, April 21, 2011). Protests in uganda over rising prices grow violent. The New York Times

Lagi, M., Bertrand, K. Z., \& Bar-Yam, Y. (2011). The food crises and political instability in north africa and the middle east. ArXiv Preprint arXiv:1108.2455, , 1-15. Retrieved from http://arxiv.org/pdf/1108.2455v1.pdf

Loibl, W., \& Toetzer, T. (2003). Modeling growth and densification processes in suburban regions-simulation of landscape transition with spatial agents. Environmental Modelling \& Software, 18(6), 553-563.

Mail and Guardian. (2007, November 9, 2007). Mauritanian govt says food riots engineered. Mail and Guardian

Majumdar, B. (2007, October 12, 2007). Food riots expose how corruption hurts india's poor. Reuters

Mangwiro, C. (2010, September 7, 2010). Mozambique to reverse bread price hikes: Minister. Reuters

Maxwell, D., Webb, P., Coates, J., \& Wirth, J. (2010). Fit for purpose? rethinking food security responses in protracted humanitarian crises. Food Policy, 35(2), 91-97. doi:10.1016/j.foodpol.2009.10.002

McDoom, O. (2011, January 31, 2011). Sudanese student dies after protests - activists. Reuters 
Morrison, J. (2012, October 7, 2012). Embassy row: Unrest in haiti. The Washington Times

Mukherjee, K., Sharma, G., \& Tait, P. (2008). Food riots and indian floods destroy 250,000 homes. Reuters

Natalini, D., Jones, A. W., \& Bravo, G. (2015). Quantitative assessment of political fragility indices and food prices as indicators of food riots in countries. Sustainability, 7(4), 4360-4385.

Naylor, R. L., Battisti, D. S., Vimont, D. J., Falcon, W. P., \& Burke, M. B. (2007). Assessing risks of climate variability and climate change for indonesian rice agriculture. Proceedings of the National Academy of Sciences of the United States of America, 104(19), 7752-7757. doi:0701825104

NBC News. (2008, May 5, 2008). Two killed as somalis riot over high food prices. NBC News Ng, T. L., Eheart, J. W., Cai, X., \& Braden, J. B. (2011). An agent-based model of farmer decisionmaking and water quality impacts at the watershed scale under markets for carbon allowances and a second-generation biofuel crop. Water Resources Research, 47(9). doi:10.1029/2011WR010399

O'Brien, T. (2012). Food riots as representations of insecurity: Examining the relationship between contentious politics and human security. Conflict, Security \& Development, 12(1), 31-49. doi:10.1080/14678802.2012.667660

OECD. (2012). Fragile states 2013: Resource flows and trend in a shifting world. (). Paris: OECD. Pasqualino, R., Jones, A. W., Monasterolo, I., \& Phillips, A. (2015). Understanding global systems Today-A calibration of the World3-03 model between 1995 and 2012. Sustainability, 7(8), 9864-9889. doi:10.3390/su7089864

Pflanz, M. (2011, August 5, 2011). Starving somalis shot dead as riots break out food supplies. The Telegraph

Puma, M. J., Bose, S., Chon, S. Y., \& Cook, B. I. (2015). Assessing the evolving fragility of the global food system. Environmental Research Letters, 10(2), 024007. doi:10.1088/17489326/10/2/024007

Purvis, A., Boggess, W. G., Moss, C. B., \& Holt, J. (1995). Technology adoption decisions under irreversibility and uncertainty: An ex ante appproach. American Journal of Agricultural Economics, 77(3), 541-551.

R Core Team. (2013). R: A language and environment for statistical computing (software). Vienna, Austria: R Foundation for Statistical Computing.

Railsback, S. F., \& Grimm, V. (2012). Agent-based and individual-based modeling: A practical introduction. Princeton, NJ: Princeton University Press.

Raleigh, C., Choi, H. J., \& Kniveton, D. (2015). The devil is in the details: An investigation of the relationships between conflict, food price and climate across africa. Global Environmental Change, 32, 187-199. doi:10.1016/j.gloenvcha.2015.03.005

Reese, F. (2014, June 5, 2014). World bank report warns of increased rioting as food prices rise. Mint Press News

Rianovosti. (2011, February 1, 2011). Three die in bread riots in egypt. Rianovosti

Rosegrant, M. W., \& Cline, S. A. (2003). Global food security: Challenges and policies. Science, 302(5652), 1917-1919. doi:10.1126/science.1092958

Sánchez-Maroño, N., Alonso-Betanzos, A., Fontenla-Romero, O., Polhill, J. G., \& Craig, T. (2015). Designing decision trees for representing sustainable behaviours in agents. In Bajo, J., Hernández, J. Z., Mathieu, P., Campbell, A., Fernández-Caballero, A., Moreno, M. N., Julián, V., Alonso-Betanzos, 
A., Jiménez-López, M. D., Botti, V. (Eds.), Trends in practical applications of agents, multi-agent systems and sustainability (pp. 169-176) Springer.

Sanders, E. (2008, September 28, 2008). Darfur front lines may be shifting to camps. Chicago Tribune

Schmidhuber, J., \& Tubiello, F. N. (2007). Global food security under climate change. Proceedings of the National Academy of Sciences of the United States of America, 104(50), 19703-19708. doi:0701976104

Schneider, M. (2008). "We are hungry!" A summary report of food riots, government responses, and states of democracy in 2008. Unpublished manuscript.

Schoen, J. W. (2011, January 14, 2011). Global food chain stretched to the limit. NBC News

Schweitzer, F., Fagiolo, G., Sornette, D., Vega-Redondo, F., Vespignani, A., \& White, D. R. (2009).

Economic networks: The new challenges. Science, 325(5939), 422-425. doi:10.1126/science.1173644

Scoop. (2008, 5 September, 2008). Food riot at refugee camp in darfur. Scoop

Seddon, D., \& Walton, J. (1994). Free markets and food riots: The politics of global adjustment. Oxford: Blackwell Publishers.

Sela, R., \& Simonoff, J. (2011). REEMtree: Regression trees with random effects (R package)

Smith, T. G. (2014). Feeding unrest disentangling the causal relationship between food price shocks and sociopolitical conflict in urban africa. Journal of Peace Research, 51(6), 679-695. doi: $10.1177 / 0022343314543722$

Sneyd, L. Q., Legwegoh, A., \& Fraser, E. D. (2013). Food riots: Media perspectives on the causes of food protest in africa. Food Security, 5(4), 485-497. doi:10.1007/s12571-013-0272-x

Squazzoni, F. (2012). Agent-based computational sociology. Chicester: Wiley.

Technology Review. (2013, July 24, 2013). South africa, riots and the price of food. Technology Review

The Associated Press. (2013, August 21, 2013). Third day of protests by farmers, truckers rattle colombia. Neweurope

The Daily Telegraph. (2011, January 10, 2011). Culprits sought after deadly riots. The Daily Telegraph

The Times of India. (2008, April 12, 2008). Food riots erupt near bangladesh capital. The Times of India

The Times Of India Delhi. (2010, August 15, 2010). Relief convoys raided in pakistan food riots. The Times of India Delhi, pp. 30.

Thiele, J., Kurth, W., \& Grimm, V. (2011). Agent-and individual-based modelling with NetLogo: Introduction and new NetLogo extensions. Tagung Deutscher Verband Forstlicher Forschungsanstalten Sektion Forstliche Biometrie, 22(68), 101.

UN. (2014). Comtrade [database]

USA TODAY. (2007, June 25, 2007). Somalia: Food riot leaves 5 dead. USA Today

Vega, V. (2013, 30 September, 2013). Venezuela faces riots due to food shortage. Ecuador Times 
Waddell, P. (2000). A behavioral simulation model for metropolitan policy analysis and planning: Residential location and housing market components of UrbanSim. Environment and Planning B, 27(2), 247-264.

WB. (2015a). Food price crisis observatory - food riot radar (database) World Bank - Food Price Watch.

WB. (2015b). The worldwide governance indicators - political stability and absence of violence methodology. Unpublished manuscript.

WB. (2015c). World bank governance indicators methodology - political stability and absence of $\begin{array}{llll}\text { violence } \quad \text { indicator fatabase). } & \text { Retrieved }\end{array}$ http://info.worldbank.org/governance/wgi/index.aspx\#doc

Worth, R. F. (2008, February 25, 2008). Rising inflation creates unease in middle east. The New York Times

Zhang, T., Zhan, J., Huang, J., Yu, R., \& Shi, C. (2013). An agent-based reasoning of impacts of regional climate changes on land use changes in the three-river headwaters region of china. Advances in Meteorology, 2013 doi:10.1155/2013/248194

\section{Appendix 1 Database of food riot updated from Natalini, et al. (2015)}

Table 5 Monthly food riots with references for the period $2005-2013$. Rows in bold are the entries added from the authors to the original database from Natalini, et al. (2015).

\begin{tabular}{|c|c|c|c|c|c|c|c|c|}
\hline Country & 2005 & 2007 & 2008 & 2009 & 2010 & 2011 & 2012 & 2013 \\
\hline Burundi & $\begin{array}{l}\text { April } \\
\text { (BBC } \\
\text { News, } \\
2005 \text { ) }\end{array}$ & & & & & & & \\
\hline Somalia & & $\begin{array}{l}\text { June (USA } \\
\text { TODAY, } \\
\text { 2007) }\end{array}$ & $\begin{array}{l}\text { May (NBC } \\
\text { News, } \\
2008)\end{array}$ & & & $\begin{array}{l}\text { August } \\
\text { (Pflanz, } \\
\text { 2011) }\end{array}$ & & \\
\hline India & & $\begin{array}{l}\text { October } \\
\text { (Majumda, } \\
2007 \text { ) }\end{array}$ & $\begin{array}{l}\text { August } \\
\text { (Mukherje } \\
\mathrm{e} \text {, et al., } \\
2008 \text { ) }\end{array}$ & & $\begin{array}{l}\text { September } \\
\text { (WB, } \\
2015 \mathrm{a})\end{array}$ & & & \\
\hline Mauritania & & $\begin{array}{l}\text { November } \\
\text { (Mail and } \\
\text { Guardian, } \\
\text { 2007) }\end{array}$ & & & & & & \\
\hline Cameroon & & & $\begin{array}{l}\text { February } \\
\text { (Healy and } \\
\text { Munckton, } \\
2008 \text { ) }\end{array}$ & & & & & \\
\hline $\begin{array}{l}\text { Burkina } \\
\text { Faso }\end{array}$ & & & $\begin{array}{l}\text { February } \\
\text { (Healy and } \\
\text { Munckton, } \\
2008 \text { ) }\end{array}$ & & & & & \\
\hline Senegal & & & $\begin{array}{l}\text { February } \\
\text { (Healy and } \\
\text { Munckton, } \\
2008 \text { ) }\end{array}$ & & & & & \\
\hline Ethiopia & & & $\begin{array}{l}\text { February } \\
\text { (Healy and } \\
\text { Munckton, } \\
2008 \text { ) }\end{array}$ & & & & & \\
\hline
\end{tabular}




\begin{tabular}{|c|c|c|c|c|c|}
\hline $\begin{array}{l}\text { Cote } \\
\text { d'Ivoire }\end{array}$ & $\begin{array}{l}\text { April } \\
\text { (BBC } \\
\text { News, } \\
2008 b \text { ) } \\
\end{array}$ & & & & \\
\hline Haiti & $\begin{array}{l}\text { April } \\
\text { (Christie, } \\
\text { et al., } \\
2008)\end{array}$ & & & 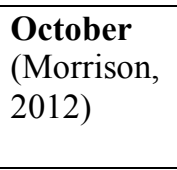 & \\
\hline Yemen & $\begin{array}{l}\text { March } \\
\text { (Worth, } \\
2008 \text { ) }\end{array}$ & & & & \\
\hline Morocco & $\begin{array}{l}\text { February } \\
\text { (Worth, } \\
2008 \text { ) }\end{array}$ & & & & \\
\hline Lebanon & $\begin{array}{l}\text { February } \\
\text { (Worth, } \\
\text { 2008) }\end{array}$ & & & & \\
\hline Egypt & $\begin{array}{l}\text { April } \\
\text { (BBC } \\
\text { News, } \\
\text { 2008a) }\end{array}$ & & $\begin{array}{l}\text { January } \\
\text { (Rianovost } \\
\text { i, 2011) }\end{array}$ & & \\
\hline Tunisia & $\begin{array}{l}\text { June } \\
\text { (Schneider, } \\
\text { 2008) }\end{array}$ & & $\begin{array}{l}\text { January } \\
\text { (Aburawa, } \\
\text { 2011) }\end{array}$ & & \\
\hline Sudan & $\begin{array}{l}\text { August } \\
\text { (Sanders, } \\
\text { 2008) }\end{array}$ & & $\begin{array}{l}\begin{array}{l}\text { January } \\
\text { (McDoom, } \\
\text { 2011) }\end{array} \\
\end{array}$ & & \\
\hline $\begin{array}{l}\text { Mozambiq } \\
\text { ue }\end{array}$ & $\begin{array}{l}\text { February } \\
\text { (Schneider, } \\
2008 \text { ) }\end{array}$ & $\begin{array}{l}\text { September } \\
\text { (Mangwiro } \\
\text { 2010) }\end{array}$ & & & \\
\hline Algeria & & & $\begin{array}{l}\text { January } \\
\text { (The Daily } \\
\text { Telegraph, } \\
\text { 2011) }\end{array}$ & & \\
\hline Oman & & & $\begin{array}{l}\text { February } \\
\text { (Aljazeera, } \\
\text { 2011) }\end{array}$ & & \\
\hline Iraq & & & $\begin{array}{l}\text { February } \\
\text { (Al-Salhy, } \\
\text { 2011) }\end{array}$ & & \\
\hline Uganda & & & $\begin{array}{l}\text { April } \\
\text { (Kron, } \\
\text { 2011) }\end{array}$ & & \\
\hline Syria & & & $\begin{array}{l}\text { September } \\
\text { (Asian } \\
\text { Correspon } \\
\text { dent, 2013) }\end{array}$ & & \\
\hline $\begin{array}{l}\text { Banglades } \\
\mathrm{h}\end{array}$ & $\begin{array}{l}\text { February } \\
\text { (The } \\
\text { Times of } \\
\text { India, } \\
2008 \text { ) }\end{array}$ & & & & \\
\hline Guinea & $\begin{array}{l}\text { June } \\
\text { (Schneider, } \\
\text { 2008) }\end{array}$ & & & & \\
\hline Kenya & $\begin{array}{l}\text { May } \\
\text { (Schoen, } \\
\text { 2011) }\end{array}$ & & & & \\
\hline Afghanista & April & & & & \\
\hline
\end{tabular}




\begin{tabular}{|c|c|c|c|c|c|c|}
\hline $\mathrm{n}$ & $\begin{array}{l}\text { (IRIN } \\
\text { News, } \\
2008)\end{array}$ & & & & & \\
\hline Chad & $\begin{array}{l}\text { September } \\
\text { (Scoop, } \\
\text { 2008) }\end{array}$ & & & & & \\
\hline Honduras & $\begin{array}{l}\text { April } \\
\text { (WB, } \\
2015 a)\end{array}$ & & & & & \\
\hline $\begin{array}{l}\text { Madagasca } \\
\mathrm{r}\end{array}$ & $\begin{array}{l}\text { April } \\
\text { (Schneider, } \\
2008 \text { ) }\end{array}$ & & & & & \\
\hline Peru & $\begin{array}{l}\text { April and } \\
\text { July } \\
\text { (Schneider, } \\
2008 \text { ) }\end{array}$ & & & & & \\
\hline $\begin{array}{l}\text { Trinidad } \\
\text { and } \\
\text { Tobago }\end{array}$ & $\begin{array}{l}\text { April } \\
\text { (Schneider, } \\
\text { 2008) }\end{array}$ & & & & & \\
\hline Zambia & $\begin{array}{l}\text { May (WB, } \\
2015 \mathrm{a})\end{array}$ & & & & & \\
\hline Zimbabwe & $\begin{array}{l}\begin{array}{l}\text { April } \\
\text { (Schneider, } \\
\text { 2008) }\end{array} \\
\end{array}$ & & & & & \\
\hline Pakistan & & $\begin{array}{l}\text { September } \\
\text { (Reese, } \\
\text { 2014) }\end{array}$ & $\begin{array}{l}\text { August } \\
\text { (The } \\
\text { Times Of } \\
\text { India } \\
\text { Delhi, } \\
\text { 2010) }\end{array}$ & & & \\
\hline Malawi & & & & $\begin{array}{l}\text { January } \\
(\text { Joy, 2012) }\end{array}$ & & \\
\hline Maldives & & & & $\begin{array}{l}\text { April } \\
\text { (BBC } \\
\text { News, } \\
2011) \\
\end{array}$ & & \\
\hline Argentina & & & & & $\begin{array}{l}\text { December } \\
\text { (Daily } \\
\text { Mail UK, } \\
\text { 2012) } \\
\end{array}$ & \\
\hline Iran & & & & & $\begin{array}{l}\text { October } \\
\text { (Bozorgme } \\
\text { hr, et al., } \\
2012 \text { ) }\end{array}$ & \\
\hline $\begin{array}{l}\text { South } \\
\text { Africa }\end{array}$ & & & & & $\begin{array}{l}\text { August } \\
\text { (Technolog } \\
\text { y Review, } \\
2013 \text { ) }\end{array}$ & \\
\hline Colombia & & & & & & $\begin{array}{l}\text { August } \\
\text { (The } \\
\text { Associated } \\
\text { Press, } \\
2013 \text { ) }\end{array}$ \\
\hline Venezuela & & & & & & $\begin{array}{l}\text { September } \\
\text { (Vega, } \\
\text { 2013) }\end{array}$ \\
\hline
\end{tabular}


Table 6 Random effects for the countries included in the DGSM.

\begin{tabular}{|c|c|}
\hline Country & Random-effects \\
\hline Afghanistan & $1.83 \mathrm{E}^{-03}$ \\
\hline Albania & $-5.29 \mathrm{E}^{-04}$ \\
\hline Algeria & $1.83 \mathrm{E}^{-03}$ \\
\hline American Samoa & $-5.29 \mathrm{E}^{-04}$ \\
\hline Andorra & $-5.29 \mathrm{E}^{-04}$ \\
\hline Angola & $-5.53 \mathrm{E}^{-04}$ \\
\hline Antigua and Barbuda & $-5.29 \mathrm{E}^{-04}$ \\
\hline Argentina & $3.61 \mathrm{E}^{-03}$ \\
\hline Armenia & $-5.29 \mathrm{E}^{-04}$ \\
\hline Aruba & $-5.29 \mathrm{E}^{-04}$ \\
\hline Australia & $-5.29 \mathrm{E}^{-04}$ \\
\hline Austria & $-5.29 \mathrm{E}^{-04}$ \\
\hline Azerbaijan & $-9.14 \mathrm{E}^{-04}$ \\
\hline Bahamas & $-5.29 \mathrm{E}^{-04}$ \\
\hline Bahrain & $-1.54 \mathrm{E}^{-03}$ \\
\hline Bangladesh & $1.83 \mathrm{E}^{-03}$ \\
\hline Barbados & $-5.29 \mathrm{E}^{-04}$ \\
\hline Belarus & $-5.29 \mathrm{E}^{-04}$ \\
\hline Belgium & $-5.29 \mathrm{E}^{-04}$ \\
\hline Belize & $-5.29 \mathrm{E}^{-04}$ \\
\hline Benin & $-5.29 \mathrm{E}^{-04}$ \\
\hline Bermuda & $-5.29 \mathrm{E}^{-04}$ \\
\hline Bhutan & $-5.29 \mathrm{E}^{-04}$ \\
\hline Bolivia & $-9.14 \mathrm{E}^{-04}$ \\
\hline Bosnia and Herzegovina & $-1.20 \mathrm{E}^{-03}$ \\
\hline Botswana & $-5.29 \mathrm{E}^{-04}$ \\
\hline Brazil & $-5.29 \mathrm{E}^{-04}$ \\
\hline Brunei Darussalam & $-5.29 \mathrm{E}^{-04}$ \\
\hline Bulgaria & $-5.29 \mathrm{E}^{-04}$ \\
\hline Burkina Faso & $2.60 \mathrm{E}^{-03}$ \\
\hline Burundi & $1.83 \mathrm{E}^{-03}$ \\
\hline Cambodia & $-5.29 \mathrm{E}^{-04}$ \\
\hline Cameroon & $2.60 \mathrm{E}^{-03}$ \\
\hline Canada & $-5.29 \mathrm{E}^{-04}$ \\
\hline Cape Verde & $-5.29 \mathrm{E}^{-04}$ \\
\hline Cayman Islands & $-5.29 \mathrm{E}^{-04}$ \\
\hline Central African Republic & $-2.31 \mathrm{E}^{-03}$ \\
\hline Chad & $1.83 \mathrm{E}^{-03}$ \\
\hline Chile & $-5.29 \mathrm{E}^{-04}$ \\
\hline China & $-1.54 \mathrm{E}^{-03}$ \\
\hline Colombia & $1.83 \mathrm{E}^{-03}$ \\
\hline Comoros & $-8.90 \mathrm{E}^{-04}$ \\
\hline
\end{tabular}




\begin{tabular}{|c|c|}
\hline Congo Dem. Rep. & $-2.31 \mathrm{E}^{-03}$ \\
\hline Congo Rep. & $-9.14 \mathrm{E}^{-04}$ \\
\hline Costa Rica & $-5.29 \mathrm{E}^{-04}$ \\
\hline Cote d'Ivoire & $1.83 \mathrm{E}^{-03}$ \\
\hline Croatia & $-5.29 \mathrm{E}^{-04}$ \\
\hline Cuba & $-5.29 \mathrm{E}^{-04}$ \\
\hline Curacao & $-5.29 \mathrm{E}^{-04}$ \\
\hline Cyprus & $-5.29 \mathrm{E}^{-04}$ \\
\hline Czech Republic & $-5.29 \mathrm{E}^{-04}$ \\
\hline Denmark & $-5.29 \mathrm{E}^{-04}$ \\
\hline Djibouti & $-5.53 \mathrm{E}^{-04}$ \\
\hline Dominica & $-5.29 \mathrm{E}^{-04}$ \\
\hline Dominican Republic & $-5.29 \mathrm{E}^{-04}$ \\
\hline Ecuador & $-1.25 \mathrm{E}^{-03}$ \\
\hline Egypt Arab Rep. & $6.36 \mathrm{E}^{-03}$ \\
\hline El Salvador & $-5.29 \mathrm{E}^{-04}$ \\
\hline Equatorial Guinea & $-5.29 \mathrm{E}^{-04}$ \\
\hline Eritrea & $-1.95 \mathrm{E}^{-03}$ \\
\hline Estonia & $-5.29 \mathrm{E}^{-04}$ \\
\hline Ethiopia & $1.83 \mathrm{E}^{-03}$ \\
\hline Faeroe Islands & $-5.29 \mathrm{E}^{-04}$ \\
\hline Fiji & $-5.29 \mathrm{E}^{-04}$ \\
\hline Finland & $-5.29 \mathrm{E}^{-04}$ \\
\hline France & $-5.29 \mathrm{E}^{-04}$ \\
\hline French Polynesia & $-5.29 \mathrm{E}^{-04}$ \\
\hline Gabon & $-5.29 \mathrm{E}^{-04}$ \\
\hline Gambia & $-5.29 \mathrm{E}^{-04}$ \\
\hline Georgia & $-1.95 \mathrm{E}^{-03}$ \\
\hline Germany & $-5.29 \mathrm{E}^{-04}$ \\
\hline Ghana & $-5.29 \mathrm{E}^{-04}$ \\
\hline Greece & $-5.29 \mathrm{E}^{-04}$ \\
\hline Greenland & $-5.29 \mathrm{E}^{-04}$ \\
\hline Grenada & $-5.29 \mathrm{E}^{-04}$ \\
\hline Guam & $-5.29 \mathrm{E}^{-04}$ \\
\hline Guatemala & $-1.95 \mathrm{E}^{-03}$ \\
\hline Guinea & $1.83 \mathrm{E}^{-03}$ \\
\hline Guinea-Bissau & $-1.54 \mathrm{E}^{-03}$ \\
\hline Guyana & $-8.90 \mathrm{E}^{-04}$ \\
\hline Haiti & $5.98 \mathrm{E}^{-03}$ \\
\hline Honduras & $3.23 \mathrm{E}^{-03}$ \\
\hline Hong Kong SAR & $-5.29 \mathrm{E}^{-04}$ \\
\hline Hungary & $-5.29 \mathrm{E}^{-04}$ \\
\hline Iceland & $-5.29 \mathrm{E}^{-04}$ \\
\hline India & $1.01 \mathrm{E}^{-02}$ \\
\hline Indonesia & $-2.28 \mathrm{E}^{-03}$ \\
\hline
\end{tabular}




\begin{tabular}{|c|c|}
\hline Iran Islamic Rep. & $1.83 \mathrm{E}^{-03}$ \\
\hline Iraq & $1.83 \mathrm{E}^{-03}$ \\
\hline Ireland & $-5.29 \mathrm{E}^{-04}$ \\
\hline Isle of Man & $-5.29 \mathrm{E}^{-04}$ \\
\hline Israel & $-2.31 \mathrm{E}^{-03}$ \\
\hline Italy & $-5.29 \mathrm{E}^{-04}$ \\
\hline Jamaica & $-5.29 \mathrm{E}^{-04}$ \\
\hline Japan & $-5.29 \mathrm{E}^{-04}$ \\
\hline Jordan & $-1.23 \mathrm{E}^{-03}$ \\
\hline Kazakhstan & $-5.29 \mathrm{E}^{-04}$ \\
\hline Kenya & $1.83 \mathrm{E}^{-03}$ \\
\hline Kiribati & $-5.29 \mathrm{E}^{-04}$ \\
\hline Korea Dem. Rep. & $-8.66 \mathrm{E}^{-04}$ \\
\hline Korea Rep. & $-5.29 \mathrm{E}^{-04}$ \\
\hline Kosovo & $-1.67 \mathrm{E}^{-03}$ \\
\hline Kuwait & $-5.29 \mathrm{E}^{-04}$ \\
\hline Kyrgyz Republic & $-1.95 \mathrm{E}^{-03}$ \\
\hline Lao PDR & $-5.29 \mathrm{E}^{-04}$ \\
\hline Latvia & $-5.29 \mathrm{E}^{-04}$ \\
\hline Lebanon & $1.83 \mathrm{E}^{-03}$ \\
\hline Lesotho & $-5.29 \mathrm{E}^{-04}$ \\
\hline Liberia & $-1.30 \mathrm{E}^{-03}$ \\
\hline Libya & $-1.54 \mathrm{E}^{-03}$ \\
\hline Liechtenstein & $-5.29 \mathrm{E}^{-04}$ \\
\hline Lithuania & $-5.29 \mathrm{E}^{-04}$ \\
\hline Luxembourg & $-5.29 \mathrm{E}^{-04}$ \\
\hline Macao SAR & $-5.29 \mathrm{E}^{-04}$ \\
\hline Macedonia FYR & $-9.14 \mathrm{E}^{-04}$ \\
\hline Madagascar & $2.27 \mathrm{E}^{-03}$ \\
\hline Malawi & $3.61 \mathrm{E}^{-03}$ \\
\hline Malaysia & $-5.29 \mathrm{E}^{-04}$ \\
\hline Maldives & $3.61 \mathrm{E}^{-03}$ \\
\hline Mali & $-1.54 \mathrm{E}^{-03}$ \\
\hline Malta & $-5.29 \mathrm{E}^{-04}$ \\
\hline Marshall Islands & $-5.29 \mathrm{E}^{-04}$ \\
\hline Mauritania & $2.24 \mathrm{E}^{-03}$ \\
\hline Mauritius & $-5.29 \mathrm{E}^{-04}$ \\
\hline Mexico & $-1.54 \mathrm{E}^{-03}$ \\
\hline Micronesia Fed. Sts. & $-5.29 \mathrm{E}^{-04}$ \\
\hline Moldova & $-5.29 \mathrm{E}^{-04}$ \\
\hline Monaco & $-5.29 \mathrm{E}^{-04}$ \\
\hline Mongolia & $-5.29 \mathrm{E}^{-04}$ \\
\hline Montenegro & $-4.15 \mathrm{E}^{-04}$ \\
\hline Morocco & $3.28 \mathrm{E}^{-03}$ \\
\hline Mozambique & $7.75 \mathrm{E}-03$ \\
\hline
\end{tabular}




\begin{tabular}{|c|c|}
\hline Myanmar & $-2.31 \mathrm{E}^{-03}$ \\
\hline Namibia & $-5.29 \mathrm{E}^{-04}$ \\
\hline Nepal & $-2.31 \mathrm{E}^{-03}$ \\
\hline Netherlands & $-5.29 \mathrm{E}^{-04}$ \\
\hline New Caledonia & $-5.29 \mathrm{E}^{-04}$ \\
\hline New Zealand & $-5.29 \mathrm{E}^{-04}$ \\
\hline Nicaragua & $-5.29 \mathrm{E}^{-04}$ \\
\hline Niger & $-1.90 \mathrm{E}^{-03}$ \\
\hline Nigeria & $-2.31 \mathrm{E}^{-03}$ \\
\hline Northern Mariana Islands & $-5.29 \mathrm{E}^{-04}$ \\
\hline Norway & $-5.29 \mathrm{E}^{-04}$ \\
\hline Oman & $3.61 \mathrm{E}^{-03}$ \\
\hline Pakistan & $5.98 \mathrm{E}^{-03}$ \\
\hline Palau & $-5.29 \mathrm{E}^{-04}$ \\
\hline Panama & $-5.29 \mathrm{E}^{-04}$ \\
\hline Papua New Guinea & $-1.92 \mathrm{E}^{-03}$ \\
\hline Paraguay & $-1.92 \mathrm{E}^{-03}$ \\
\hline Peru & $2.19 \mathrm{E}^{-03}$ \\
\hline Philippines & $-2.31 \mathrm{E}^{-03}$ \\
\hline Poland & $-5.29 \mathrm{E}^{-04}$ \\
\hline Portugal & $-5.29 \mathrm{E}^{-04}$ \\
\hline Puerto Rico & $-5.29 \mathrm{E}^{-04}$ \\
\hline Qatar & $-5.29 \mathrm{E}^{-04}$ \\
\hline Romania & $-5.29 \mathrm{E}^{-04}$ \\
\hline Russian Federation & $-1.95 \mathrm{E}^{-03}$ \\
\hline Rwanda & $-5.77 \mathrm{E}^{-04}$ \\
\hline Samoa & $-5.29 \mathrm{E}^{-04}$ \\
\hline San Marino & $-5.29 \mathrm{E}^{-04}$ \\
\hline Sao Tome and Principe & $-5.29 \mathrm{E}^{-04}$ \\
\hline Saudi Arabia & $-5.29 \mathrm{E}^{-04}$ \\
\hline Senegal & $3.61 \mathrm{E}^{-03}$ \\
\hline Serbia & $-5.53 \mathrm{E}^{-04}$ \\
\hline Seychelles & $-5.29 \mathrm{E}^{-04}$ \\
\hline Sierra Leone & $-5.29 \mathrm{E}^{-04}$ \\
\hline Singapore & $-5.29 \mathrm{E}^{-04}$ \\
\hline Sint Maarten (Dutch part) & $-5.29 \mathrm{E}^{-04}$ \\
\hline Slovak Republic & $-5.29 \mathrm{E}^{-04}$ \\
\hline Slovenia & $-5.29 \mathrm{E}^{-04}$ \\
\hline Solomon Islands & $-5.29 \mathrm{E}^{-04}$ \\
\hline Somalia & $1.01 \mathrm{E}^{-02}$ \\
\hline South Africa & $3.61 \mathrm{E}^{-03}$ \\
\hline South Sudan & $-8.14 \mathrm{E}^{-04}$ \\
\hline Spain & $-5.29 \mathrm{E}^{-04}$ \\
\hline Sri Lanka & $-2.31 \mathrm{E}^{-03}$ \\
\hline St. Kitts and Nevis & $-5.29 \mathrm{E}^{-04}$ \\
\hline
\end{tabular}




\begin{tabular}{|l|l|}
\hline St. Lucia & $-5.29 \mathrm{E}^{-04}$ \\
\hline St. Martin (French part) & $-5.29 \mathrm{E}^{-04}$ \\
\hline St. Vincent and the Grenadines & $-5.29 \mathrm{E}^{-04}$ \\
\hline Sudan & $5.98 \mathrm{E}^{-03}$ \\
\hline Suriname & $-5.29 \mathrm{E}^{-04}$ \\
\hline Swaziland & $-8.66 \mathrm{E}^{-04}$ \\
\hline Sweden & $-5.29 \mathrm{E}^{-04}$ \\
\hline Switzerland & $-5.29 \mathrm{E}^{-04}$ \\
\hline Syrian Arab Republic & $2.27 \mathrm{E}^{-03}$ \\
\hline Tajikistan & $-1.95 \mathrm{E}^{-03}$ \\
\hline Tanzania & $-5.29 \mathrm{E}^{-04}$ \\
\hline Thailand & $-2.31 \mathrm{E}^{-03}$ \\
\hline Timor-Leste & $-6.01 \mathrm{E}^{-04}$ \\
\hline Togo & $-8.90 \mathrm{E}^{-04}$ \\
\hline Tonga & $-5.29 \mathrm{E}^{-04}$ \\
\hline Trinidad and Tobago & $3.61 \mathrm{E}^{-03}$ \\
\hline Tunisia & $7.08 \mathrm{E}^{-03}$ \\
\hline Turkey & $-1.92 \mathrm{E}^{-03}$ \\
\hline Turkmenistan & $-5.29 \mathrm{E}^{-04}$ \\
\hline Turks and Caicos Islands & $-5.29 \mathrm{E}^{-04}$ \\
\hline Tuvalu & $-5.29 \mathrm{E}^{-04}$ \\
\hline Uganda & $1.83 \mathrm{E}^{-03}$ \\
\hline Ukraine & $-8.66 \mathrm{E}^{-04}$ \\
\hline United Arab Emirates & $-5.29 \mathrm{E}^{-04}$ \\
\hline United Kingdom & $-5.29 \mathrm{E}^{-04}$ \\
\hline United States & $-5.29 \mathrm{E}^{-04}$ \\
\hline Uruguay & $-5.29 \mathrm{E}^{-04}$ \\
\hline Uzbekistan & $-1.97 \mathrm{E}^{-03}$ \\
\hline Vanuatu & $-5.29 \mathrm{E}^{-04}$ \\
\hline Venezuela RB & $1.83 \mathrm{E}^{-03}$ \\
\hline Vietnam & $-5.29 \mathrm{E}^{-04}$ \\
\hline Virgin Islands U.S. & $-5.29 \mathrm{E}^{-04}$ \\
\hline West Bank and Gaza & $-2.31 \mathrm{E}^{-03}$ \\
\hline Yemen Rep. & $1.83 \mathrm{E}^{-03}$ \\
\hline Zambia -03 \\
\hline Zimbabwe & \\
\hline
\end{tabular}

